\title{
NÁSTIN PROCESU ZANIKÁNÍ SÍDEL VE STŘEDOVĚKU NA PANSTVÍ BRTNICE V ÚZEMNÍM ROZSAHU K ROKU 1538
}

\author{
JANA MAZÁČKOVÁ
}

\begin{abstract}
Abstrakt: Př́spěvek využivá $k$ nástinu procesu zanikání sídel na panství Brtnice především jejich výčet a přerozdělení zemédělské půdy z jejich zázemí v urbáři brtnického panství vzniklého kolem roku 1538. Urbár̆ uvádí sedmnáct zaniklých vesnic, dvůr a pusté lány. Zmínky o majetkových převodech a hledání možného obdobi zániku v pisemných pramenech je u některých lokalit podloženo i prospekci antropogennich reliktů přmo v krajině. Zaniklé osidlení vesnického charakteru se zemédělským zázemím představuje v pisemných pramenech zajímavý prvek majetkových transakcí, ze kterých lze odvodit nakládání se středověkou krajinou a jejím vymezenim.
\end{abstract}

Klíčová slova: pisemné prameny - urbár̆ - knihy půhonné - zemské desky - zaniklé osidleni - zaniklé vesnice-zemědělské zázemí-panství-těžba drahých kovi̊-hrad-vývoj osídlení.

An Outline of the Process of Abandonment of Settlement Sites in the Brtnice Demesne as of the Year 1538 Abstract: This contribution employs a list of settlement sites in the Brtnice demesne, along with the division of farmland in their hinterland recorded in an urbarium of the Brtnice demesne that came into existence around 1538, to outline the process of their abandonment. The urbarium lists seventeen abandoned villages, a homestead and disused land. Mentions of property transfers and a search for the possible period of decline in written sources are supplemented, with some locations, with prospection for anthropogennous relics in the landscape. Defunct settlement sites of a village character with a farming hinterland present in written sources interesting elements of property transactions, from which the use of the medieval landscape and its delimitations can be derived.

Key words: written sources - urbarium - prosecution registers - land registers - defunct settlement-abandoned villages - farming hinterland-demesne-mining precious metals - castle-settlement development.

\section{Úvod}

Při zkoumání zázemí hradu Rokštejna, k. ú. Panská Lhota, a jeho ekonomického potenciálu se vychází z dlouhodobé prospekce širokého území především zalesněné krajiny v povodí řek Jihlávky, Brtnice a Jihlavy. Kombinují se data lidaru, historického mapování a samotného průchodu krajinou. Navazuje se na terénní prospekce regionu prováděné již v druhé polovině 20. století s publikačními výstupy Z. Měřínského a V. Navrátila (Měřínský 1976, 405-417; Navrátil 1986; 1986a; Mazáčková-Doležalová 2012). Detekce a zaměřování vesnických sídel $\mathrm{s}$ jejich plužinou vede k rekonstrukci sídelní sítě a hustoty osídlení se zemědělským využíváním krajiny především pro 13. až 15 . století a poukazuje na intenzivní změny v krajině a jejím vegetačním pokryvu. Vedle zemědělství se v krajině výrazně projevuje těžba stříbra a stopy po rýžování i dolování zlata, které představují ekonomické zaměření především ve 13. a 14. století (Vokáč-Houzar-Škrdla 2007, 26-55; Hrubý a kol. 2014, 38-45; Losertová a kol. 2011, 1-10; Měřínský-Zumpfe 2001, 25). S př́íchodem Valdštejnů a jejich získáním a sloučením rokštejnského a brtnického panství dosáhlo i osídlení v tomto regionu maxima. Archeologické, ale i písemné prameny naznačují jako kolizní pro existenci a zánik vesnic s možným vlivem válečných událostí konec 14. a druhou polovinu až konec 15. století. Skupování zaniklých sídel Valdštejny uzavírá krizové zánikové období po ukončení česko-uherských válek a budování kompaktního panství jako silného ekonomického základu, které dokumentují první soupisy zaniklých sídel z tohoto regionu v urbářích brtnického panství.

\section{Zkoumané území}

Zkoumané území zahrnuje především bývalé panství Brtnice (obr. 1) v hranicích zmiňovaných prvním urbářem panství zřízeného k roku 1538 (MZA, fond G 10, inv. č. 638) a okolí 
jeho hranic do vzdálenosti $5 \mathrm{~km}$. Prozatím výrazným předělem v terénní prospekci je tok řeky Jihlavy a jejího levobřeží. Zkoumaný úsek zahrnuje převážně povodí řek Brtnice, Jihlavy a Jihlávky. Panství v hranicích do roku 1538 se rozkládalo na Českomoravské vrchovině v rámci jejího podcelku Křižanovské vrchoviny. Nadmořská výška se pohybuje mezi $405-635 \mathrm{~m} \mathrm{n}$. m. (Demek-Mackovčin 2006, 32-33, 188, 368, 415, 515). Hlavními toky regionu jsou řeka Jihlava a její př́ítoky Jihlávka a Brtnice.

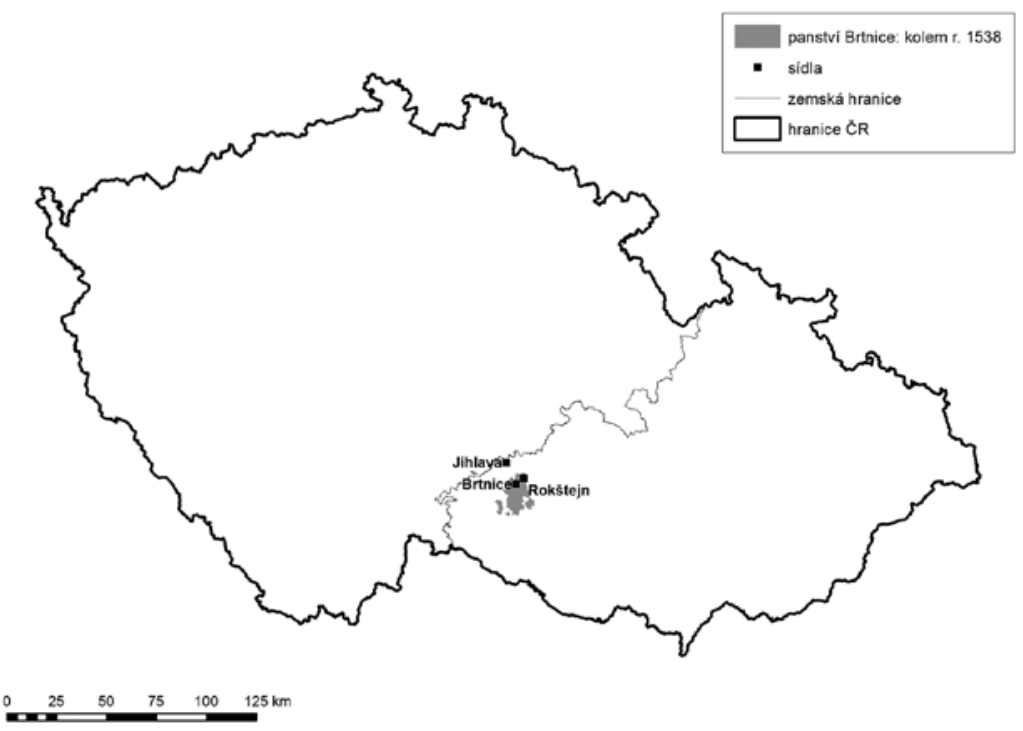

Obr. 1. Panství Brtnice v hranicích kolem roku 1538.

Abb. 1. Herrschaft Pirnitz in den Grenzen von um 1538.

\section{Prospekce zaniklých sídel}

Povrchová prospekce a zaměření antropogenních reliktů, které lze ztotožnit se zaniklým osídlením nebo přímo se specifickým zaniklým osídlením, jako jsou zaniklé středověké vesnice $\mathrm{s}$ doložitelným původním názvem, náleží k základním a stěžejním pramenům poznání středověkého osídlení v oblasti. Vytváŕí se jedinečný komplex faktů na jednom místě, ovlivňovaném po zániku osídlení různými př́rodním a antropogenními procesy, např́íklad zpětným zalesněním při změně vlastníka panství, které mohlo zakonzervovat nebo i výrazně snížit výpovědní hodnotu souborů. Ve zkoumaném území jsou doložitelné výrazné antropogenní relikty, které představují zbytky původních vesnických sídel se zemědělskou ekonomikou. Jedná se o lokality situované v současné době např́íklad v prostoru lesa Sokolíčko, lesa Lhotka, lesa Aleje a lesa Zákopy. Zalesnění je doloženo na historických mapách, a to na Müllerově mapě Moravy, mapách I. a II. vojenského mapování i na indikačních skicách. Zalesněnou oblast dokumentují také archivní mapy lesních revírů jednotlivých panství Jihlava nebo Brtnice a vývoj přibližují i pomístní názvy (MZA, fond F 16, mapa 1033). Les Sokolíčko, les Lhotka a les V Zákopech jihozápadně od Opatova reprezentují hospodářské lesy bez záměrného přeparcelování, $\mathrm{k}$ jakému došlo u lesa Aleje, který dostál významné změny mezi lety 1815-1817 v rámci výstavby loveckého zámečku knížetem Eduardem Collalto (Samek 1994, 262). Na rod Collaltů přešlo brtnické panství v roce 1623 , př̀i konfiskacích provedených po Bílé hoře. Patrně po třicetileté válce došlo k zalesnění uváděných revírů Sokolíčko, Lhotka, Aleje a V Zákopech (obr. 2).

Aplikované prospekční metody vedou k rozpoznání a k definování tvarů a funkcí antropogenních reliktů. Zaměření jednotlivých sídel převádí informace o reliktech do GIS prostředí 


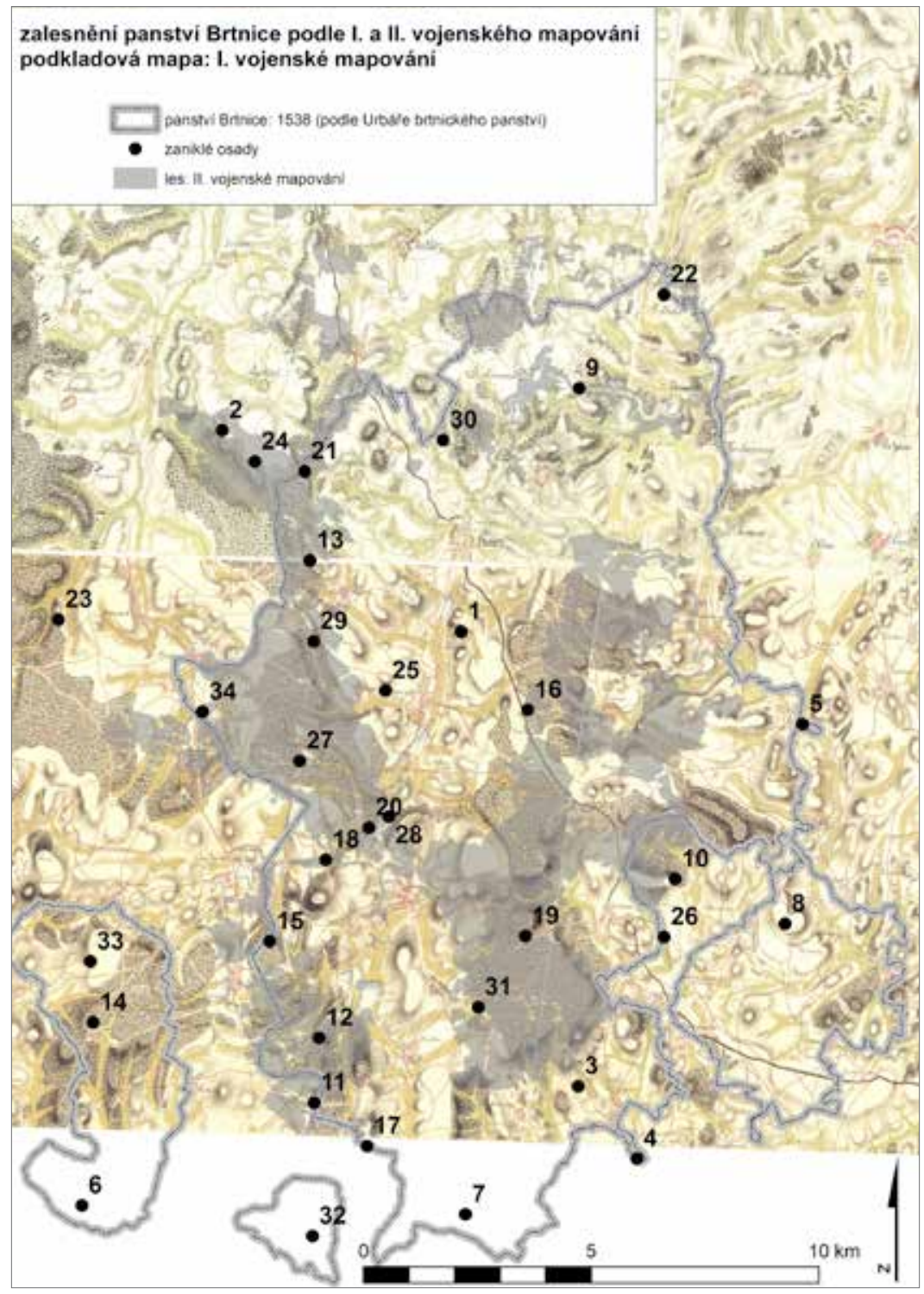

Obr. 2. Doložené zaniklé osídlení vesnického typu a zalesnění panství Brtnice na I. a II. vojenském mapování (I. vojenské mapování nelze správně rektifikovat se stávajícími mapovými podklady). 1 - Brtnice-Bukovec (Kněžice-Čihadla), 2 - Pod Suchou - mlýn, 3 - Bezděkov, 4 - Březová, 5 - Čertovec, 6 - Čížov, 7 - Dašovice, 8 - Dobrkovice, 9 - Doubkov, 10 - Hofeřice, 11 - Jeníšov I, 12 - Jeníšov II, 13 - Lhota/ Lhotka, 14 - Lipolec, 15 - Loučky, 16 - Malé Petrůvky, 17 - Malý Štítek, 18 - Martinice, 19 - Mosty, 20 Opatov-Červené Žlíbky, 21 - Ostejkovice, 22 - Ozřetín, 23 - Pfaffendorf, 24 - Regenholz, 25 - Šamonín, 26 - Skalky, 27 - Služanov, 28 - Stančice, 29 - Strážov, 30 - Střenčí, 31 - Velké Petrủvky, 32 - Velký Štítek, 33 - Veselí/Veselá, 34 - Zhořec.

Abb. 2. Belegte Siedlungswüstungen dörflichen Typs und Aufforstung der Herrschaft Pirnitz auf der I. und II. militärischen Kartierung. Die I. militärische Kartierung lässt sich mit den derzeitigen Kartenunterlagen nicht richtig rektifizieren. 1 - Brtnice-Bukovec (Kněžice-Čihadla), 2 - Pod Suchou - Mühle, 3 - Bezděkov, 4 - Březová, 5 - Čertovec, 6 - Čížov, 7 - Dašovice, 8 - Dobrkovice, 9 - Doubkov, 10 - Hofeřice, 11 - Jeníšov I, 12 - Jeníšov II, 13 - Lhota/Lhotka, 14 - Lipolec, 15 - Loučky, 16 - Malé Petrủvky, 17 - Malý Štítek, 18 - Martinice, 19 - Mosty, 20 - Opatov-Červené Žlíbky, 21 - Ostejkovice, 22 - Ozřetín, 23 - Pfaffendorf, 24 - Regenholz, 25 - Šamonín, 26 - Skalky, 27 - Služanov, 28 - Stančice, 29 - Strážov, 30 - Střenčí, 31 - Velké Petrůvky, 32 - Velký Štítek, 33 - Veselí/Veselá, 34 - Zhořec. 
a umožňuje kvalitnější vyhodnocování i interpretaci. Sestavení půdorysu sídla a rekonstrukce parcelace a její zástavby ovlivňuje setřelost reliktů. S intravilánem se zkoumá i extravilán sídla, a to veškerá možná půda náležící $\mathrm{k}$ jedné vesnici jako její zázemí. V těchto případech se na základě terénních reliktů a využití vektorizovaných historických map (indikační skica, I. a II. vojenské mapování) hledají a indikují původní polní systémy, zatravněné plochy nebo zalesněná území a současně hranice vesnického zázemí. V rámci zkoumaného území lze objevit i jiné druhy zaniklých antropogenních reliktů, např́iklad úvozy a jejich systémy, zaniklá vodní díla, těžební a zpracovatelské areály jako lomy a těžební jámy na písek nebo hlínu a mnohé jiné. Při terénní prospekci probíhá povrchový sběr artefaktů z narušených situací a metodicky ustálená systematická prospekce detektorem kovů s geodetickým zaměřením a formalizovaným popisem pro vyhodnocení souboru artefaktů ve vztahu k antropogenním reliktům v GIS prostředí. Při prospekci se odebírají půdní vzorky pomocí pedologické sondy. Lze tak zjistit základní zvrstvení na zkoumaném prostoru, získávají se vzorky pro geochemické a archeobotanické analýzy důležité pro rekonstrukci př́rodní prostředí.

Jednou ze zásadních otázek je příčina zániku zkoumaných sídel doložitelná v archeologických nebo historických pramenech. Pro poznání náhlého nebo postupného zanikání sídel $\mathrm{v}$ průběhu 15. století, u některých z nich převrstveného druhotným zemědělským využíváním v průběhu 16. století, je důležitý předchozí vývoj a zjištěné ekonomiky. Ve zkoumaném prostoru se totiž objevují sídla s vazbou na důlní činnost, zemědělství a jejich kombinace.

Mezi lety 1399-1538 lze doložit na panství brtnických Valdštejnů (panství Rokštejn-Brtnice) znalost osídlení dvojího typu, a to sídla kontinuálně existující a sídla pustá s evidencí v písemných pramenech a s přerozdělováním jejich plužiny. Třetí samostatnou skupinu vytváŕí zaniklé vesnice, které nejsou evidovány v pramenech 15 . nebo 16 . století jako zaniklé a jejichž půda se nepřerozděluje. Jedná se o sídla zaniklá bez kontinuálního povědomí nebo spíše nutnosti dokládat jejich existenci, protože jejich ekonomické zázemí nebylo vyměřeno a právně pevně vymezeno. S jejich geografickým vymezením nebylo potřeba při majetkových transakcích dále počítat. Vznik těchto sídel je spojen, v souladu s první písemnou zmínkou o nich, většinou již s první polovinou 13. století. Ve 13. století významně narůstají písemné doklady o osídlení regionu. Podle jejich rekonstrukce se objevují lokality na řekách Brtnici, Jihlávce a Jihlavě. Do listinného fundamentu $\mathrm{k}$ dějinám osídlení náleží tzv. přibyslavická listina hlásící se $\mathrm{k}$ roku 1224, listiny z let 1226 a 1227 potvrzující majetek želivského kláštera, biskupské konfirmace z roku 1233 o Jihlavě a Brtnici, markraběcí dary tišnovskému klášteru z roku 1234, dále Václavovy listiny z let 1238 a 1240 o přesunech majetků a listiny olomouckého biskupa Bruna z roku 1257 o desátkových vesnicích jihlavského kostela. Někde při zemské hranici v okolí Třeště byl lovětínský újezd, který do roku 1227 držel správce bítovské provincie Petr. Nejstarší osídlení je kladeno písemnými prameny do prostoru Kněžic a Přibyslavic, se kterými souvisí již výše zmiňovaná tzv. přibyslavická listina. Nelokalizovatelné osady z listinného materiálu 13. století uvádí například listina z roku 1233 pro jihlavský kostel. Sídla se zde uvádí patrně v geografické následnosti, přesto část $\mathrm{z}$ nich nelze spojit se stávajícím nebo i v současné době s identifikovaným zaniklým osídlením (CDB II, 274-276 č. 281; CDB II, 275 č. 281; CDB III/1, 4-5 č. 6; CDB III, 43-44 č. 43; CDB III, 49-50 č. 49; CDM II, 256 č. 234; CDB III, 97-100 č. 88; CDB III, 223-225 č. 180; CDB III, 353-356 č. 260; CDB V/1, 209-210 č. 130; CDM III, 241-242 č. 253; Hosák 1952, 142-147; CDB II, 207-208 č. 222; Měřínský 1990, 129-141).

Valdštejnové se snaží o územní zisky se zaniklým i zanikajícím osídlením již od počátku svého příchodu do regionu - jako př́íklad poslouží zaniklá ves Lhotka. Vesnice zanikla již na konci 14. století. Jako Elhotu nebo Legotu písemných pramenů 13. století ji uvádějí J. Z. Charouz a Z. Měřínský a před nimi již o století dříve A. J. Pátek. Její spojení s prameny 13. století však neodpovídá geografickému výčtu uváděných sídel, protože vystupuje až za Smrčnou severně od Jihlavy (Charouz-Měřínský 2009, 41; Pátek 1901, 6). I když Jestřebí původně náleželo k markraběcímu dědictví, zapsal jej i s pustou Lhotkou Beneš z Libuně Hynkovi z Valdštejna (ZDB VIII, 229 č. 232). Při majetkovém narovnání dvou generací Valdštejnů v roce 1444 držel Zdeněk z Valdštejna hrad v Brtnici s městečkem, Jestřebí, pustou Lhotku, Uhřínovice, Lhotu, 


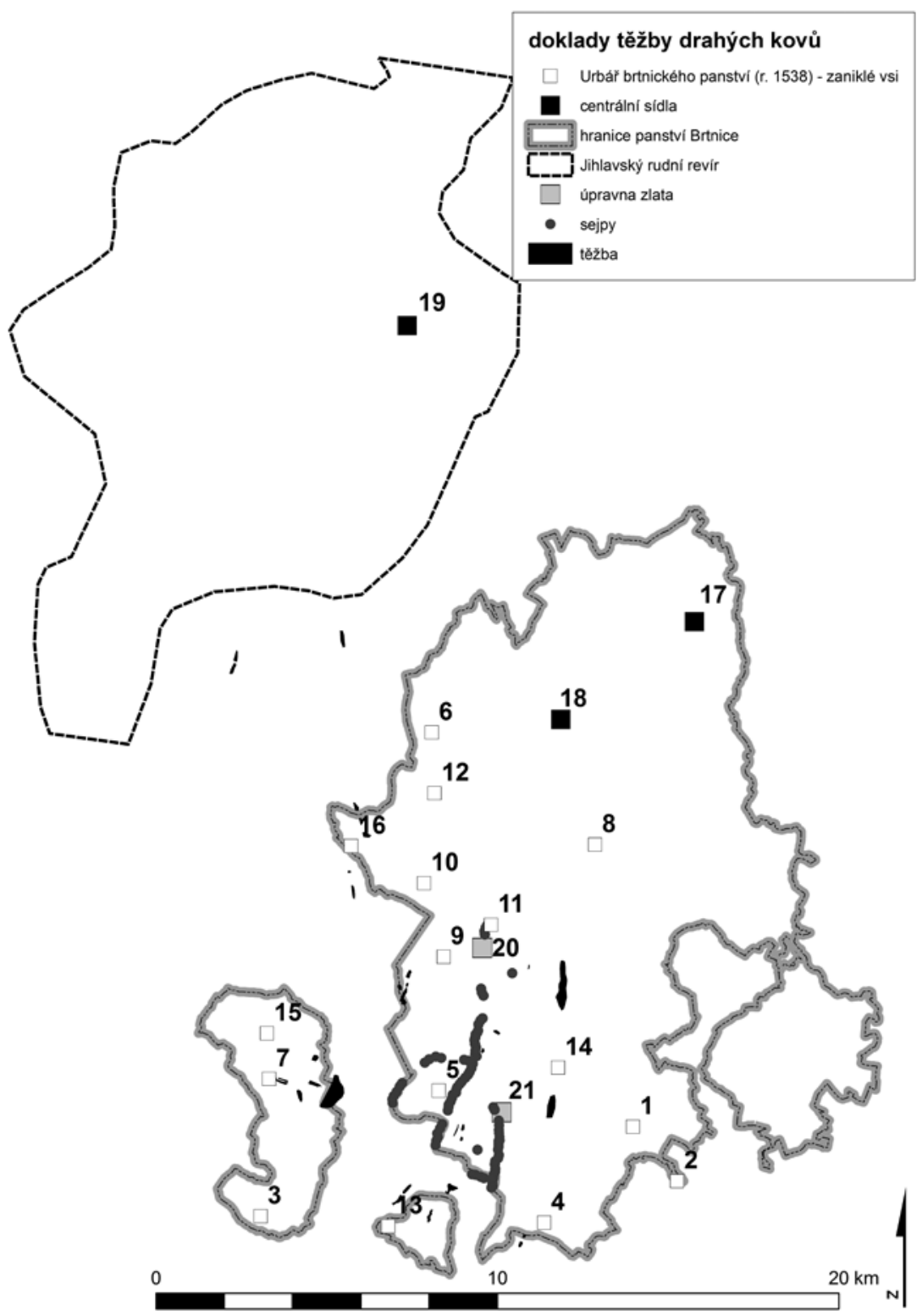

Obr. 3. Zaniklé osady uvedené v urbáři brtnického panství k roku 1538, centrální místa regionu a doklady těžby drahých kovủ nebo rýžování (jihlavský rudní revír podle Hrubý a kol. 2006, 176, obr. 6; doklady sejpů podle provedené terénní prospekce a Vokáč-Houzar-Škrdla 2007, 3, obr. 1). 1 - Bezděkov, 2 - Březová, 3 - Čížov, 4 - Dašovice, 5 - Jeníšov II, 6 - Lhota/Lhotka, 7 - Lipolec, 8 - Malé Petrůvky, 9 - Martinice, 10 - Stančice, 11 - Strážov, 12 - Střenčí, 13 - Svojkovice, 14 - Velké Petrůvky, 15 - Veselí/Veselá, 16 - Zhořec, 17 - Rokštejn, 18 - Brtnice, 19 - Jihlava, 20 - Zlatomlýn, 21 - Opatov.

Abb. 3. Im Urbarium der Grundherrschaft Pirnitz zum Jahr 1538 aufgeführte Siedlungswüstungen, Zentralorte der Region und Belege für Edelmetall- oder Goldgewinnung (Iglauer Erzrevier nach Hrubý et al. 2006, 176, Abb. 6; Belege für Abraumhalden gemäß der durchgeführten Geländeprospektion und Vokáč-HouzarŠkrdla 2007, 3, Abb. 1). 1 - Bezděkov, 2 - Březová, 3 - Čížov, 4 - Dašovice, 5 - Jeníšov II, 6 - Lhota/Lhotka, 7 - Lipolec, 8 - Malé Petrůvky, 9 - Martinice, 10 - Stančice, 11 - Strážov, 12 - Střenčí, 13 - Svojkovice, 14 Velké Petrůvky, 15 - Veselí/Veselá, 16 - Zhořec, 17 - Rokštejn, 18 - Brtnice, 19 - Jihlava, 20 - Zlatomlýn, 21 - Opatov. 
Malé, Stř́ižov, Přímělkov, Smrčné, kostelní podací v Čáslavicích „a $k$ tomu zbožie hrad Vrchní i Dolni Rukštein“ (AČ IX, 273-275 č. 32; AČ XIV, 11-12 č. 1497; Měřínský-Plaček 1989, 15-16; Měřínský 2007, 54-56). V majetku brtnických Valdštejnů byla zaniklá ves Lhotka uváděna jako pustá v roce 1399, opětovně v roce 1444 a později i v urbáŕích brtnického panství ze 16. století. Jedná se o vyměřenou vesnici, která se jako komplex původní zástavby a zemědělského zázemí objevuje v podobě konstantní pozemkové jednotky. Zemské desky reflektují majetkové převody pustých sídel a mladší prameny prokazují jejich zemědělské využívání bez vazby na znovuosídlení pustiny. Přesně definované zázemí pustých vsí nacházelo výrazné uplatnění v systému zemědělského hospodaření a ekonomických plánů nových majitelů (ZDB VIII, 229 č. 232; AČ IX, 273-275 č. 3; MZA, fond G 10, inv. č. 638).

Valdštejnské panství Brtnice mělo mezi lety 1399-1538 jedno město (Brtnice), jedno městečko (Heraltice), jeden až dva hrady (Rokštejn, Brtnice) a třicet existujících vesnic, k roku 1669 uvádí lánový rejstřík k sídelnímu městu se zámkem v Brtnici tři městečka (Heraltice, Opatov, Stará Říše) a celkem 28 vesnic (MZA, fond G 10, inv. č. 638; MZA, fond D 1, poř. č. 256, sign. 268). První ucelený soupis zaniklých vsí s přerozdělením plužiny představuje urbář brtnického panství vzniklý před rokem 1538 (MZA, fond G 10, inv. č. 638, fol. 85-113). Udává především soupis existujících městeček a vsí brtnického panství: Brtnice, Trhová, Kněžice, Opatov, Stará Říše, Malé Brtničky, Jestřebí, Uhřínovice, Komárovice, Stř́ǐžov, Malý, Lhota, Smrčný, Bransouze, Chlum, Číchov, Radonín, Rychlov, Víska, Brodce, Hrutov, Předín, Heraltice, Zašovice, Petrovice, Krahulov, Čechočovice, Krahulov, Hvězdoňovice, Chlístov, Štěměchy, Čáslavice a Přímělkov (MZA, fond G 10, inv. č. 638, fol. 1-84). Vedle nich urbář eviduje 17 zaniklých vsí nebo pustých lánů, a to Dašovice, Březová, Bezděčkov, Petrůvky, Svojkovice, Čížov, Veselý, Lipulec, Jeníšov, Petrůvky Malé, Martinice, Strážov, Stančice, Střenčie, Lhotka, Popustých láních, Zhořec a Žilkovský dvůr (obr. 3). Archeologicky je doložitelných 27 zaniklých středověkých vesnic na území panství Brtnice v hranicích z roku 1538 (obr. 4).

Významné majetkové převody $\mathrm{v}$ druhé polovině 15 . století připojily $\mathrm{k}$ brtnickým majetkům poměrně rozsáhlá území vytvářející územně kompaktní celek. Valdštejnské ambice vybudovat dominium bez vklíněných drobných panství se projevily hned na počátku jejich příchodu do regionu. Nedořešená otázka svobodného nakládání s hradem Rokštejnem je vyvážena přebudováním brtnického hradu.

Důkazem o držbě Rokštejna je i listina z roku 1444 o dělení rodového majetku. Vystupují zde zapsané majetky v zemských deskách jako Střížov, Přímělkov, Smrčné nebo kostelní podací v Č́slavicích, Jestř̌ebí a pustá Lhotka, v roce 1437 zapsané Lhoty (Panské Lhoty) a Malý vedle v zemských deskách neuváděných Rokštejna a Brtnice. Ta zde vystupuje na prvním místě, ale dochovanou korespondenci z let 1447-1449 Zdeněk z Valdštejna vždy koncipoval na Rokštejně a zde přistupuje i k Vildštajnské mírové dohodě roku 1450 (AČ IX, 273 č. 32; AČ II, 282-283 č. 45; AČ III, 544 č. 546; AČ III, 545 č. 558; AČ II, 284-286 č. 46). Hrad Rokštejn je zde uváděn jako zbožie Horní a Dolní Rukštajn a listinný popis tak respektuje stavební uspořádání hradní lokality. V roce 1466 si Valdštejnové stěžují na zisky Mikuláše z Rochova, ale sami praktikují tvrdé uvazování se v cizí majetky, které geograficky sousedí s jejich panstvím, a jsou za ně poháněni k zemskému soudu (ZDB XIV, 413, 414 č. 30, 34). Od roku 1480 pravděpodobně i v souvislosti s převodem panství a hradu Sádek Lichtemburkům a následně pánům z Hradce skupovali Valdštejnové statky v širším okolí Brtnice (ZDB XV, 22 č. 198; AČ X, 353 č. 130). Jejich ekonomická situace se po období nepokojů v souvislosti s česko-uherskými válkami a v mezidobí před mírovým vyrovnáním výrazně nezhoršila a Valdštejnové si udrželi potenciál ke skupování majetků sousedících s brtnickým panstvím. Mezi nové zisky náleželo kněžické zboží, včetně Kněžic, došlo ke koupi Rychlova, Větrova, Petrůvek, Mostů, Martinic a dvou ,pluhư role“ ve Strážově (ZDB XV, 7 č. 25). Dále se brtnické panství rozrostlo o Komárovice, Starou Říši, Opatov s prríslušenstvím a pusté Lipuovce (Lipolec) a pusté Veselé (ZDB XV, 13 č. 100; ZDB XV, 19 č. 164; ZDB XV, 23 č. 205). Hynek z Valdštejna své manželce Dorotě z Lípy zapisuje vedle věna 100 zlatých uherských i majetky na Opatově a Staré Říši (ZDB XV, 23 č. 208). V roce 1481 je poháněn Hynek želivským klášterem, že se uvázal v Brodce, Hrutov a Vésku. O majetky se 


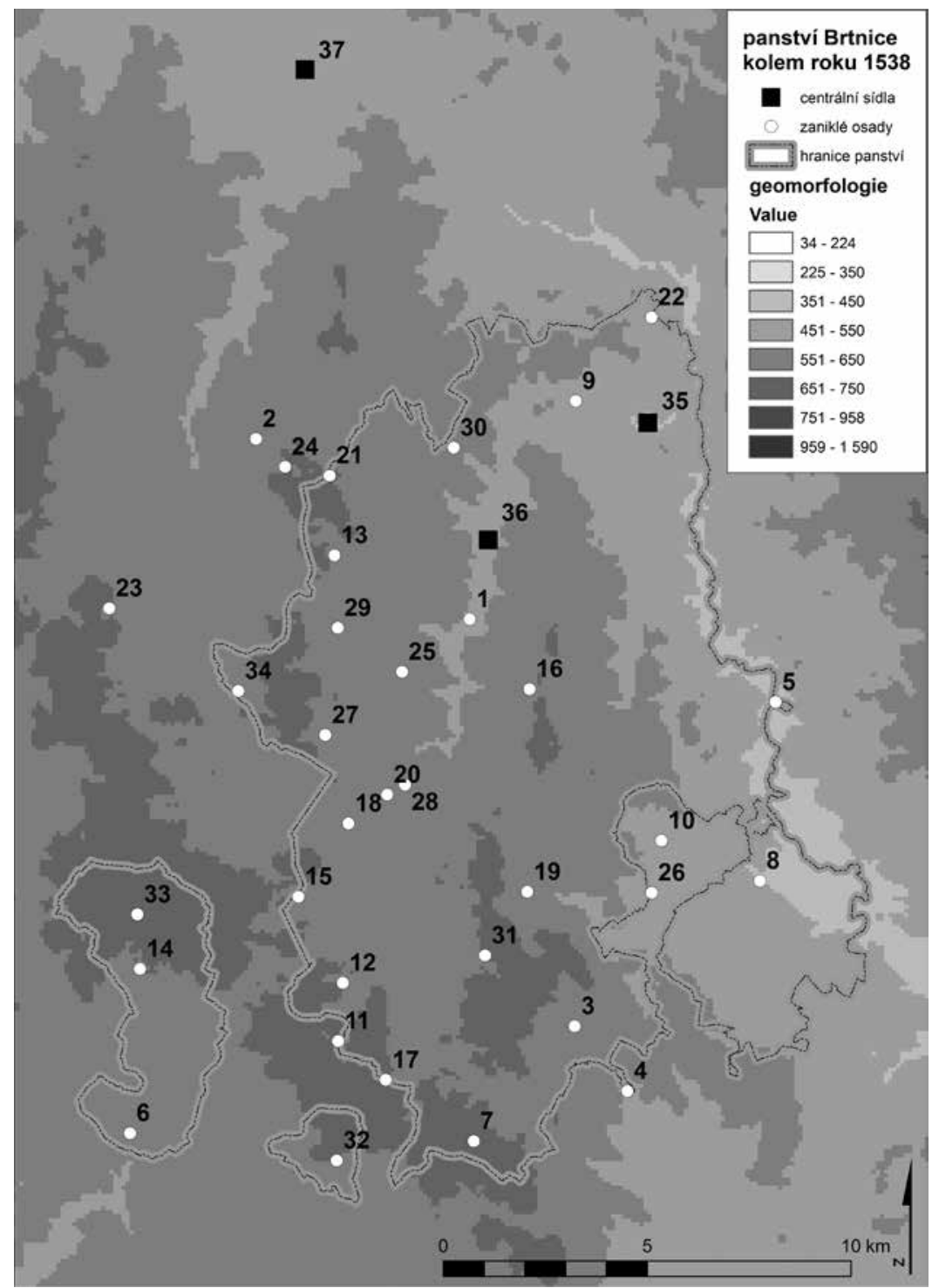

Obr. 4. Geomorfologie zkoumaného regionu s vazbou na zaniklé osídlení na panství Brtnice nebo v jeho blízkém okolí na území s provedenou terénní prospekcí a vyhledáním antropogenních reliktů. 1 - Brtnice-Bukovec (Kněžice-Čihadla), 2 - Pod Suchou - mlýn, 3 - Bezděkov, 4 - Březová, 5 - Čertovec, 6 - Čížov, 7 - Dašovice, 8 - Dobrkovice, 9 - Doubkov, 10 - Hofeřice, 11 - Jeníšov I, 12 - Jeníšov II, 13 - Lhota/ Lhotka, 14 - Lipolec, 15 - Loučky, 16 - Malé Petrůvky, 17 - Malý Štítek, 18 - Martinice, 19 - Mosty, 20 Opatov-Červené Žlíbky, 21 - Ostejkovice, 22 - Ozřetín, 23 - Pfaffendorf, 24 - Regenholz, 25 - Šamonín, 26 - Skalky, 27 - Služanov, 28 - Stančice, 29 - Strážov, 30 - Střenčí, 31 - Velké Petrủvky, 32 - Velký Štítek, 33 - Veselí/Veselá, 34 - Zhořec, 35 - Rokštejn, 36 - Brtnice, 37 - Jihlava.

Abb. 4. Geomorphologie der untersuchten Region mit Bezug zu den Siedlungswüstungen in der Herrschaft Pirnitz oder in deren näheren Umgebung in dem Gebiet mit durchgeführter Geländeprospektion und vorgefundenen anthropogenen Relikten. 1 - Brtnice-Bukovec (Kněžice-Čihadla), 2 - Pod Suchou Mühle, 3 - Bezděkov, 4 - Březová, 5 - Čertovec, 6 - Čí̌̌ov, 7 - Dašovice, 8 - Dobrkovice, 9 - Doubkov, 10 - Hofeřice, 11 - Jeníšov I, 12 - Jeníšov II, 13 - Lhota/Lhotka, 14 - Lipolec, 15 - Loučky, 16 - Malé Petrůvky, 17 - Malý Štítek, 18 - Martinice, 19 - Mosty, 20 - Opatov-Červené Žlíbky, 21 - Ostejkovice, 22 - Ozřetín, 23 - Pfaffendorf, 24 - Regenholz, 25 - Šamonín, 26 - Skalky, 27 - Služanov, 28 - Stančice, 29 - Strážov, 30 - Střenčí, 31 - Velké Petrůvky, 32 - Velký Štítek, 33 - Veselí/Veselá, 34 - Zhořec, 35 Rokštejn, 36 - Brtnice, 37 - Jihlava. 
hlásil i Jan Jeníček, protože Hynek držel statky třebíčského kláštera zabrané jako válečné zboží. Ještě téhož roku byl poháněn Machnou i Dorotou z Budče o 200 zlatých z odkoupení poloviny Staré Říše, dále Lipolce a Veselíčka. O Opatov vedla spor Dorota z Př́iseky. Kněz Zebald pohání Hynka za držení lidí v Radoníně, vsi Čertovce, ulice v Přibyslavicích a mlýna tamtéž (LCS V, 279, 285-286, 288-289, 291, 303, 306, 314, 319, 340, 347, 387, 441 č. 69, 105, 108-109, 121-122, 136, 207, 228, 273, 298, 424, 465, 678, 221; Zaoralová 1988, 105).

Mezi lety 1493 a 1495 Valdštejnové získali části vsi Střenčí, od roku 1499 ves Krahulov, tvrz Čechočovice a Petrovice. V roce 1505 k panství připadly ves a tvrz ve Štěměchách s dvorem a mlýnem, Předín s kostelním podacím, v městečku Heralticích šest lánů a dva podsedky, v Zašovicích tři a čtvrt lánu, v Bransouzích pět lánů s podsedkem a mlýništěm a řekou, ve vsi Hvězdoňovice dvůr s lánem a s mlýnem, ve vsi Chlístov tři lány, pusté Petrůvky, Březová, Bezděkov, Dašovice, Svojkovice, Jeníšov a Č́ižov (ZDB XVI, 61 č. 216; ZDB XVI, 72 č. 262; ZDB XVII, 99 č. 110; ZDB XVII, 119 č. 215; Zaoralová 1988, 106). Odkup panství Oldřicha Mládence prripojilo $\mathrm{k}$ brtnickému panství především bývalé hornické osady zanikající v průběhu druhé poloviny 15. století, z nichž většina přežila česko-uherské války a je zmiňována např́íklad roku

\begin{tabular}{|c|c|c|c|c|c|c|}
\hline Lokalita & \multicolumn{2}{|c|}{ 1. písemná zmínka } & \multicolumn{2}{|r|}{ 1. zmínka o zaniklé } & \multirow{2}{*}{$\begin{array}{c}\text { Panství primární } \\
\text { z Heraltic }\end{array}$} & \multirow{2}{*}{$\begin{array}{c}\begin{array}{c}\text { Poslední } \\
\text { existence }\end{array} \\
\begin{array}{c}\text { 1490, ZDB XVI, } \\
38 \text { č. } 55\end{array}\end{array}$} \\
\hline Dašovice & 1371 & ZDB V, 92 č. 458 & $1466 / 1492$ & ZDB XVI, 48 č. 135 & & \\
\hline Březová & & & $1466 / 1492$ & ZDB XVI, 48 č. 135 & $\begin{array}{l}\text { Markvart z Hrád- } \\
\text { ku/z Heraltic }\end{array}$ & \\
\hline Bezděkov & $1466 / 1490$ & ZDB XVI, 48 č. 1355 & $1466 / 1492$ & ZDB XVI, 48 č. 135 & z Heraltic & \\
\hline Petrůvky & 1353 & ZDB II, 17 č. 73 & $1466 / 1492$ & ZDB XVI, 48 č. 135 & z Heraltic & \\
\hline Svojkovice & $1257 / 1353$ & $\begin{array}{l}\text { CDM III, } 245 \text { č. } 257 \text {; } \\
\text { ZDB II, } 17 \text { č. } 73\end{array}$ & 1466 & LCS IV/1, 228 č. 1007 & $\begin{array}{l}\text { Markvart } \\
\text { z Hrádku }\end{array}$ & \\
\hline Čížov & 1358 & ZDB I, 37 č. 408 & 1505 & ZDB II, 119 č. 215 & $\begin{array}{l}\text { Markvart } \\
\text { z Hrádku }\end{array}$ & \\
\hline Veselý & 1257 & CDM III, 245 č. 257 & 1481 & ZDB XV, 23 č. 205 & $\begin{array}{l}\text { Markvart } \\
\text { z Hrádku }\end{array}$ & \\
\hline Lipulec & 1257 & CDM III, 245 č. 257 & 1481 & ZDB XV, 23 č. 205 & $\begin{array}{l}\text { Markvart } \\
\text { z Hrádku }\end{array}$ & \\
\hline Jeníšov & 1358 & ZDB III, 32 č. 257 & $1466 / 1490$ & ZDB XVI, 48 č. 135 & Želetava & \\
\hline $\begin{array}{l}\text { Petrůvky } \\
\text { Malé }\end{array}$ & 1364 & ZDB IV, 52 č. 151 & 1538 & urbář & Dětřich z Kněžic & $\begin{array}{l}\text { 1480, ZDB XV, } \\
7 \text { č. } 25\end{array}$ \\
\hline Martinice & 1371 & ZDB V, 87 č. 329 & 1538 & urbář & Dětřich z Kněžic & $\begin{array}{l}\text { 1480, ZDB XV, } \\
7 \text { č. } 25\end{array}$ \\
\hline Strážov & 1364 & ZDB IV, 52 č. 151 & 1538 & urbáŕ & Dětřich z Kněžic & $\begin{array}{l}\text { 1480, ZDB XV, } \\
7 \text { č. } 25\end{array}$ \\
\hline \multirow{2}{*}{ Stančice } & \multirow{2}{*}{1436} & LCS III/1, & \multirow{2}{*}{1502} & \multirow{2}{*}{$\begin{array}{l}\text { LCS VII, 242, 1155-1158; LCS } \\
\text { VII, 246, 1167; LCS VII, 249, } 1183\end{array}$} & \multirow{2}{*}{ Dalešice } & \multirow{2}{*}{$\begin{array}{l}\text { 1447, ZDB XII, } \\
376 \text { č. } 687\end{array}$} \\
\hline & & 162 č. 773 & & & & \\
\hline Střenčie & 1337 & $\begin{array}{l}\text { CDM VII/1, } 105 \\
\text { č. } 134\end{array}$ & $1466 / 1538$ & LCS IV/1, 218 č. $940 \mathrm{~b}$ & zeměpanské & $\begin{array}{l}\text { 1495, ZDB XVI, } \\
72 \text { č. } 262\end{array}$ \\
\hline Lhotka & 1399 & ZDB VIII, 229 č. 232 & 1399 & ZDB VIII, 229 č. 232 & zeměpanské & \\
\hline $\begin{array}{l}\text { Popustých } \\
\text { láních }\end{array}$ & 1538 & urbář & 1538 & urbář & & \\
\hline Zhořec & 1355 & ZDB I, 24 č. 69 & 1530 & urbář & z Dlouhé Brtnice & $\begin{array}{l}1447, \text { ZDB I, } 370 \\
\text { č. } 616\end{array}$ \\
\hline $\begin{array}{l}\text { Žilkovský } \\
\text { dvůr }\end{array}$ & & & & & & \\
\hline
\end{tabular}

Tab. 1. Soupis zaniklých sídel využívaných jako zemědělské zázemí na panství Brtnice v roce 1538. Podle urbáře brtnického panství, MZA, fond G 10, inv. č. 638.

Tab. 1. Verzeichnis der Siedlungswüstungen, die im Jahr 1538 als landwirtschaftliches Hinterland genutzt wurden. Nach dem Urbarium der Herrschaft Pirnitz, Mährisches Landesarchiv, Bestand G 10, Inv.-Nr. 638. 
1480 (tab. 1). Čechočovice byly následně spojeny pro geografickou blízkost s valdštejnským panstvím Sádek. Až v roce 1547 se dostávají k brtnickému panství vsi Brodce, Víska a Hrutov, které už uvádí první urbář panství datovaný k roku 1538 (ZDB XXVI, 340 č. 220; MZA, G 10, inv. č. 638 , fol. 59-62).

\section{Vývoj středověkého osídlení regionu brtnického panství}

Vývoj osídlení Jihlavska nebo jeho jihovýchodní části Brtnicka naposledy shrnul samostatně nebo ve spolupráci s J. Z. Charouzem Z. Měřínský. Další pohled na počátky osídlení Českomoravské vrchoviny přinesla práce P. Hejhala. Nepublikované výsledky o dějinách osídlení jsou dostupné v práci J. Mazáčkové (Měřínský 1988, 13-49; 1988a, 51-99; 1990, 129-141; 1997, 151-239; Měřínský-Charouz 2009, 33-45; Hejhal 2012; Mazáčková 2012, 121-191; Vohryzek 2015, 37-44). Vývoj valdštejnského panství územně navazuje na vznik šlechtického rokštejnského panství na dolním toku Brtnice a původního zeměpanského majetku na středním toku Brtnice se stejnojmenným centrem.

První písemné zmínky o regionu spadají již do 12. století, kdy byl na jeho počátku založen klášter v Třebíči, jemu byly poskytnuty osady jihovýchodně od Brtnice jako dar Oldřicha Brněnského (Fišer 2002, 86-94; Bláhová-Frolík-Profantová 1999; Bláhová 2002; Válka 1991, $38,41)$. Jedná se o Chlum, Číchov a zaniklé Dobrkovice u Petrovic. Chlum je později zmiňován v tzv. přibyslavické listině k roku 1224. Na konci 12. století jsou uváděny v jižní části regionu majetky louckého kláštera, kterému náleželo podle zakládací listiny území kolem Rokytnice nad Rokytnou včetně tamního kostela. Jmenovány jsou Pokojovice, Lesonice, Litohoř, Domamil, Př́luk a Popovice, z nichž Př́luk nelze prozatím přesně lokalizovat. Nachází se patrně někde mezi Domamilem a Lesonicemi (CDB I, 229-301 č. 326; Válka 1991, 38, 41; Hosák 2004, 93). Třetí významnou církevní institucí vstupující razantně do prostoru na řece Jihlavě, a to převážně v regionu jejího horního toku, byl želivský klášter. Premonstráti ze Želiva byli provázáni s patronátními právy na kostel v Kněžicích, stejně jako na zdejší proboštství. Další církevní majetky představovala osada německých rytířů při brodu přes řeku Jihlavu, o které se dovídáme ve zmínce z 30. let 13. století (CDB III, 43-44 č. 43; CDB III, 48 č. 48; CDB III, 49-50 č. 49).

Zeměpanské majetky vychází z rekonstrukce posloupnosti tzv. přibyslavických listin. $\mathrm{K}$ roku 1224 jsou uváděny majetky přibyslavického kostela a nedlouho poté se jmenuje samotný královnin přibyslavický újezd (CDB III/1, 4-5 č. 6). Mezi jmenovanými osadami v majetku kostela se objevují Brtnice s krčmou, Bransouze, Číchov, Radonín, Elhota (Čertovec), Zašovice, Petrovice, Nová Ves a samozřejmě samotné Přibyslavice. Zeměpanské majetky se nacházely kolem center v Přibyslavicích a Brtnici, severně posléze v Jihlavě. Brtnice se ještě několikrát objevuje v listinách 13. století a zdejší region se jako dar dostává nejdřive tišnovskému klášteru. Jeho následné odebrání a výměna za jiné majetky souvisí patrně s nálezy stř́ibrných rud a zeměpanským zájmem v regionu. Dochází k etablování panství Brtnice vedle upadajících Přibyslavic, ve kterých stál románský zděný palác s kostelem (CDB II, 274-276 č. 281; CDB II, 275 č. 281; CDB III/1, 4-5 č. 6; CDB III, 43-44 č. 43; CDB III, 49-50 č. 49; CDM II, 256 č. 234; CDB III, 97-100 č. 88; CDB III, 223-225 č. 180; CDB III, 353-356 č. 260; CDB V/1, 209-210 č. 130; CDM III, 241-242 č. 253; CDB II, 207-208 č. 222; Hosák 1952, 142-147; Měřínský 1990, 129-141).

Nejstarší písemné zmínky o etablování šlechtických panství spadají do 20. let 13. století a jsou významným hybatelem osídlení v regionu. Etablování šlechtických panství v prostoru znojemského údělu se nejdříve datuje k roku 1222 (obr. 5). V tomto roce se objevuje jistý Theodericus de Chnesiz (Dětřich z Kněžic). Panství Dětřicha z Kněžic se mělo stát a kolem poloviny 13. století i bylo významným celkem regionu, ale ani zeměpanské služby na hradech ve Znojmě a Bítově již ke konci 13. století nezastavily úpadek dobře nastaveného formování panství. Centrum panství bylo v Kněžicích. U kostela sv. Jakuba vzniklo proboštství želivského kláštera, které spolu s darováním kostelů v Opatově a v Moravanech ukazují na silnou pozici rodu z Kněžic. Do roku 1227 byl majitelem lovětínského újezdu Petr, správce bítovské provincie, která se v pramenech objevuje poprvé roku 1222 (CDB II, 222-225 č. 234; CDB II, 303-304 č. 305; Jan 

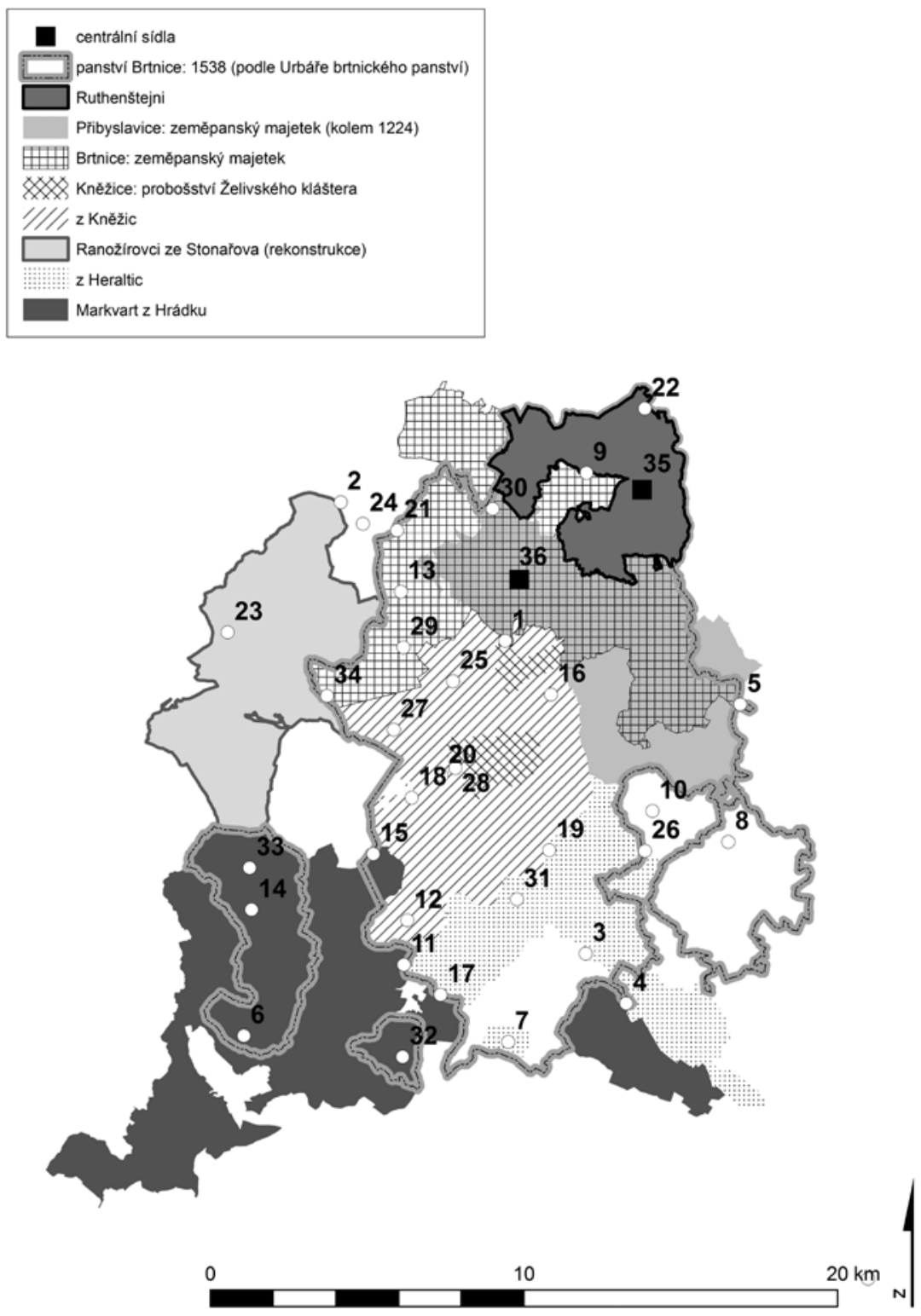

Obr. 5. Panství v regionu etablovaná do poloviny 13. století a zaniklé osady uvedené $\mathrm{v}$ urbáři brtnického panství $\mathrm{k}$ roku 1538, centrální místa regionu a místa zpracování drahých kovů: 1 - Brtnice-Bukovec (Kněžice-Čihadla), 2 - Pod Suchou mlýn, 3 - Bezděkov, 4 - Březová, 5 - Čertovec, 6 - Čížov, 7 - Dašovice, 8 - Dobrkovice, 9 - Doubkov, 10 - Hofeřice, 11 - Jeníšov I, 12 - Jeníšov II, 13 - Lhota/Lhotka, 14 - Lipolec, 15 - Loučky, 16 - Malé Petrůvky, 17 - Malý Štítek, 18 - Martinice, 19 - Mosty, 20 - Opatov-Červené Žlíbky, 21 - Ostejkovice, 22 - Ozřetín, 23 - Pfaffendorf, 24 - Regenholz, 25 - Šamonín, 26 - Skalky, 27 - Služanov, 28 - Stančice, 29 - Strážov, 30 - Střenčí, 31 - Velké Petrůvky, 32 - Velký Štítek, 33 - Veselí/ Veselá, 34 - Zhořec, 35 - Rokštejn, 36 - Brtnice.

Abb. 5. Bis Mitte des 13. Jahrhunderts in der Region etablierte Herrschaften und im Urbarium der Grundherrschaft Pirnitz zum Jahr 1538 aufgeführte Siedlungswüstungen, Zentralorte der Region und Edelmetallverarbeitungsstätten. 1 - Brtnice-Bukovec (Kněžice-Čihadla), 2 - Pod Suchou - Mühle, 3 - Bezděkov, 4 - Březová, 5 - Čertovec, 6 - Čížov, 7 - Dašovice, 8 - Dobrkovice, 9 - Doubkov, 10 - Hofeřice, 11 - Jeníšov I, 12 - Jeníšov II, 13 - Lhota/Lhotka, 14 - Lipolec, 15 - Loučky, 16 Malé Petrůvky, 17 - Malý Štítek, 18 - Martinice, 19 - Mosty, 20 - Opatov-Červené Žlíbky, 21 - Ostejkovice, 22 - Ožretín, 23 - Pfaffendorf, 24 - Regenholz, 25 - Šamonín, 26 - Skalky, 27 - Služanov, 28 - Stančice, 29 - Strážov, 30 - Střeněí, 31 Velké Petrůvky, 32 - Velký Štítek, 33 - Veselí/Veselá, 34 - Zhořec, 35 - Rokštejn, 36 - Brtnice. 
2000, 27). Lovětínský újezd představuje úsek krajiny na zemské hranici mezi Moravou a Čechami spojitelný s lovětínskou stezkou, která vedla z Počátek přes Třešt' na Brtnici a Třebíč. Lovětínský újezd je definován k roku 1227 a jeho území zahrnuje odtokovou oblast na horní Jihlavě, tedy ,aquis, que ibidem fluunt, Ihlaua et Crupi, ubicunque velit, possit, ad quemcunque locum eadem aque deriventur, piscinas et molendina licite collocare, omnium fluminum ibidem labenicium ripas hereditario iure possidendo"(CDB II, 303-304 č. 305; Hosák 1952, 142). Ani získání újezdu louckému klášteru nedovolilo se $\mathrm{v}$ oblasti více prosadit a klášter zde dále vystupuje jen jako patron kostela sv. Kunhuty v Kostelci u Jihlavy v roce 1293 (CDM IV, 402-403 č. 318).

Další šlechtické panství představovaly majetky Ranožírovců v povodí Jihlávky se sídly Rancířov, Vílanec a Stonařov. Druhý Rancířov u Dešné měl představovat jiné panství téhož rodu. V roce 1335 se uvádí šest lánů ve Vílanci jako bývalý majetek Markvarta z Rancířova. Úpadek rodu nastoupil patrně již v druhé polovině 13. století, kdy postupně přicházeli o patronátní práva a následně i o majetek. Kostel ve Vílanci měl již v roce 1333 šedesát let stejnou patronku, a to Gertrudu, vdovu po Konrádu Schoberovi z Jihlavy. Tato situace ukazuje pronikání jihlavských měšt’anů do sídel s možným výskytem stříbra a přístupem k dolování. Dalším Ranožírovcem byl Albert ze Stonařova, který prodává stonařovské majetky nejpozději roku 1366 . V prostoru při zemské hranici lze ale již v první třetině 13. století tušit snad další rod, pocházející od moravského šlechtice Wolframa. Spor o horní tok Jihlavy a les Borek se rozhořel mezi syny moravského šlechtice Wolframa a želivským klášterem. Nakonec došlo roku 1233 k narovnání a upravení sporné hranice (CDB III, 43-44 č. 43; CDM VII/1, 64 č. 83; ZDB IV, 59 č. 295, 302; ZDB IV, 67 č. 439; Měŕínský 1988, 24; 1997, 198; Hosák 1952; Vohryzek 2015, 39-44).

Po polovině 13. století se jmenují dva šlechtické rody s majetky jižně od Brtnice. Jedná se o rod píšící se po Heralticích a druhý po Hrádku. Radslav z Heraltic je jmenován ve svědecké řadě listiny Přemysla Otakara II. z roku 1256 (CDM III, 219 č. 234). K majetkům rodu z Heraltic náležely samotné Heraltice a okolní statky nebo jejich části, které se uvádí většinou až ve 14. století, jako Dašovice, Vacenovice, Svojkovice, Rokytnice, Předín, Petrovice nebo Martinice (ZDB II, 16-17 č. 71, 73). Panství pánů z Heraltic zahrnuje některé vsi z původního ř́išského panství Markvarta z Hrádku, a to Svojkovice a Petrovice/Petrůvky. Herrat z Heraltic zapisuje své manželce Elišce plat ze vsí Svojkovic, poloviny Dašovic, Petrovic a poloviny Vacenovic (ZDB II, 17 č. 73). Další z Heraltických Oldřich zapisuje plat manželce Evě tentokrát ze vsí Rokytnice, Dašovice a z Předína (ZDB V, 87 č. 334). Majetky se koncentrovaly mezi Heralticemi a Předínem, náležely k nim vesnice Rokytnice a Vacenovice a dále Svojkovice a Petrůvky z původního majetku Markvarta z Hrádku a od kněžických zakoupené Martinice. V roce 1371 započaly zajímavé majetkové převody patrně související s eskalující těžbou zlata. Janek z Heraltic prodal polovinu Předína a polovinu Dašovic Frickovi z Předína (ZDB V, 92 č. 458). O dvanáct let později v roce 1383 tentýž Fricek z Předína prodává polovinu Předína, polovinu Dašovic, ve vesnici Ruffo Martinice 7 33/4 lánu a vesnici Jeníšov hraběti Janovi z Hardeggu. Ten nechává obratem zapsat své manželce Anně osm lánů na Předíně, půl Dašovic, 7 3/4 lánů ve vsi Ruffo Martinice a ves Jeníšov (ZDB VI, 152 č. 938-941, 943). V roce 1386 se Předín a Dašovice dostávají jako intabulovaný majetek brněnskému Židovi Šavelovi (Chawel) od jisté Evy, manželky Václava, a ta od Šavela získává Chlístov a dvůr ve Vacenovicích. Následně patrně stejný Šavel (Chablinus) prodává roku 1390 jistému Rivolovi z Myslejovic Předín i Dašovice a ten roku 1399 vstupuje se svým bratrem Mikšíkem řečeným Roman do pravého spolku na tento majetek. Předín a Dašovice chce nakonec prodat v roce 1415 Anna, vdova po Markvartovi z Trmčova, a to Joštovi Hechtovi z Rosic. Proti této intabulaci vystupuje Smil z Heraltic a snaží se uplatnit své nároky na zmíněné vsi (ZDB VII, 178 č. 504-505, ZDB VII, 187 č. 659; ZDB VIII, 231 č. 282; ZDB XI 301 č. 210-211).

Další poměrně rozsáhlý šlechtický majetek se konsolidoval již kolem poloviny 13. století v okolí Staré Říše, kde na Červeném Hrádku seděl rod Markvarta z Hrádku, který měl založit se svou ženou Vojslavou klášter v Nové Říši (Hosák 2004, 37). Poměrně rozsáhlé majetky zahrnovaly i lokality provázané s těžbou zlata (Malý a Velký Štítek). Panství Markvarta z Hrádku (Marquardus de Castello), syna jisté Ludmily, lze definovat na základě jmenovaných desátkových vsí kláštera v Nové Říši k roku 1257. Mezi ně náležely Markvartice a Vojkovice, Štítek 
Velký a Malý, Hladov a Sedlatice, Olšové a Rímov, Lipolec a Veselé (Marquardiz et Woykowiz, Schytech maior et minor, Pfaffendorf et Schedelethiz, Olshowe et Rzymow, Lupolze et Wessele; CDM III, 245 č. 257). Onou Ludmilou byla Ludmila z Hradce a Markvartem byl Markvart de Thur (z Hrádku; CDM III, 101 č. 133). Rod z Hrádku a z Kněžic se provázal i prŕibuzensky s potomky Dětřicha I. z Kněžic. V roce 1278 vystupuje Markvart z Hrádku jako manžel sestry Dětřicha II. z Kněžic Agnes (vnučky prvně jmenovaného Dětřicha z roku 1222; CDB V/1, 182-184 č. 108; CDM VII/3, 774-775 č. 142). Adelheida, dcera Dětřicha z Kněžic a manželka Markvarta Dlouhého ze Slatiny, ustanovila ve své závěti poručení o statcích. Ves Kanich postoupila manželovi Markvartovi, ale bez horního práva. V jejím testamentu z roku 1278 se jmenuje i Volfram ze Slatiny (CDB V/1, 182-184 č. 108). Třetina vsi Kanich se následně dostává do rukou Markvarta z Hrádku a jeho ženy Agnes jako dědictví, Markvart jej roku 1278 prodává Vojslavovi a kostelu v Kněžicích. Na listině svědčí Dětřich z Kněžic (CDB V/2, 595 č. 872). Vojslav si činil na Kanich nárok po smrti Markvarta, a tak vymáhal na Zdeslavě, druhé manželce, své nároky a v roce 1279 uspěl u soudu ve Znojmě (CDM VII Suppl. č. 142).

Část majetků Markvarta z Hrádku a vesnic následně zakoupených do valdštejnského panství pochází ze želetavského panství nebo z vlastnictví rodů s centry panství mimo tento region, jako byli páni z Mostiště. Situaci lze demonstrovat na zaniklé vsi Jeníšov náležející Valdštejnům od roku 1499. Jeníšov od roku 1358 patřil k želetavskému panství, když jej prodal Bunco de Mosticz (Bohuněk z Mostiště) Oldřichovi ze Želetavy, který dal v roce 1364 své manželce na Jeníšově zapsat plat (ZDB III, 32 č. 257; ZDB IV, 51 č. 110). Oldřich ze Želetavy své panství, které zahrnovalo Želetavu s tvrzí a s lesy Brdem a Glag, Markvartice, Jindřichovice, Budíškovice a Štítky s doly, prodal olomouckému kanovníkovi Benešovi a jeho bratřím z Vajtmile v roce 1368 (CDM X, 29-31 č. 39). V roce 1370 uděluje markrabě Janovi z Kosovy Hory a Herešovi z Újezdce jen městečko Želetavu s tvrzí a trhem, Štítky, Markvartice a Litohoř (CDM X, 112 č. 91). Jeníšov zůstal dál v majetcích Oldřicha ze Želetavy a někdy mezi roky 1364-1379 a část ještě $\mathrm{v}$ roce 1383 byla ve vlastnictví pánů z Jakubova. Velkým majetkovým převodem vesnic spojených patrně $\mathrm{s}$ těžbou zlata se v roce 1383 dostávají Jeníšov, Dašovice, Předín a Martinice do majetků hraběte Jana z Hardegga, a to podnikatelským záměrem Fricka z Předína (ZDB IV, 138 č. 663; ZDB VI, 152 č. 938-943). Dále je uveden roku 1466 v majetku Oldřicha Mládence z Miličína, jenž byl zapsán v roce 1490 do zemských desk, a pak přechází do vlastnictví Valdštejnů (ZDB XVI, 48 č. 135).

Na základě výpovědi písemných pramenů lze pozorovat rychlý zrod a upevňování panství, které dosáhlo vrcholu mezi polovinou 13. století a koncem 13. století, mladší generace zmíněných rodů drží zmenšené majetky, a to v souvislosti s větvením rodin (viz Ranožírovci a Stonařov) nebo $\mathrm{s}$ prodeji $\mathrm{v}$ závislosti na důlním podnikání nebo úpadkem vlivu a př́stupu k zeměpanským službám a bezesporu i přirozenou cestou v důsledku vymírání rodu. Nejasná je posloupnost u kněžických Hrutovců, mezi generacemi 13. a 14. století, kteří nakonec prodávají Kněžice s vesnicí Petrovicemi a dvěma dvory ve Strážově v roce 1364 Bohuši ze Starče (ZDB IV, 52 č. 151).

\section{Archeologické doklady osídlení}

Krajina byla ovlivněna silně antropogenní činností až s probíhající středověkou kolonizací a nástupem odlesňování v průběhu 13. století, se zakládáním sídel i těžebních areálů drahých kovů. Doklady mladohradištního osídlení představuje jen sporadicky se vyskytující keramický materiál, a to v Opatově a Štěměchách (Měřínský 1986, 162-163, 225, 243). Osídlení v první polovině 13. století potvrzují nálezy užitkové keramiky obsahující tuhu a se specifickým druhem výzdoby, který se vyskytuje v úzkém časovém horizontu. Tento druh keramiky představuje konečnou fázi vývoje jihomoravské mladohradištní keramiky a dostával se na jižní Moravu z jihu přes Rakousko (Měřínský 1990, 133; 2009, 196). Z některých lokalit pochází jen několik málo kusů - jeden až dva (např. Střenčí, Staré Hory; Hrubý a kol. 2006, 209, 215, obr. 32:15), z jiných je doloženo vysoké zastoupení (ZSV Jeníšov; Vokáč-Houzar-Škrdla 2007, 36-37, obr. 5). Do 
tohoto okruhu náleží i doklady z Brtnice, Kněžic, Panské Lhoty nebo Šamonína. Z povodí Jihlávky je tento druh keramiky doložen z Vílance (Měřínský 1988, 31-33, obr. 8:9; 2014, 90-93, obr. 1; Hrazdil a kol. 2012, 137-144; Vokáč-Zimola 2011, 446).

Vedle specifických keramických výrobků lze zohlednit i architekturu. Existence kamenných, především sakrálních staveb v povodí Jihlavy, Jihlávky a Brtnice dokládá fundátorské snahy majitelů vznikajících panství v kolonizovaném prostoru. U kostelů se následně projevil fenomén darování patronátních práv, např́íklad želivskému nebo louckému klášteru. Původní stav, udržení patronátního práva, má kostel ve Vílanci, kde v roce 1327 již 60 let držela patronátní právo vdova Gertruda Schoberová z Jihlavy, které mohla získat od původních majitelů Vílance, rodu Ranožírovců. Obdobně je tomu s patronátními právy na kostel ve Stř́ižově. Ta byla získávána spolu se Stř́ižovem nebo jeho částí v průběhu 14. i 15. století (CDB III, 49-50 č. 49; CDM IV, 403-404 č. 318; CDM VII/3, 776-777 č. 147; CDM VI, 268 č. 344; ZDB VII, 202 č. 964; ZDB XII, 338 č. 181). Náleží sem v povodí Jihlavy kostely v Kostelci u Jihlavy (kostel sv. Kunhuty), v Jihlavě (kostel sv. Jana), v Přibyslavicích (kostel sv. Anny, ale původně sv. Gottharda) a v Červené Lhotě (kostel sv. Vavřince), v povodí Jihlávky ve Vílanci (kostel sv. Jakuba) a kostel sv. Václava s karnerem ve Stonařově. V povodí Brtnice jsou to kostely v Opatově (sv. Bartoloměje), Kněžicích (sv. Jakuba), Brtnici (sv. Jakuba) a Střížově (sv. Jana Křtitele). Jmenované stavby většinou náležejí mezi tzv. přechodné stavby první poloviny 13. století (Richter 1952; 1961, 23-37; Vokáč-Zimola 2011, 437-443; Bláha a kol. 2001, 114-115).

Vzhled panských sídel první poloviny 13. století až na výjimku v Přibyslavicích je neznámý. Zeměpanské sídlo doplněné románským kamenným palácem ukazuje na exkluzivitu a možnosti Konstanciiny provincie. Kamenné šlechtické sídlo hradního typu představuje až Rokštejn. Starší fortifikovaná sídla lze demonstrovat na vzhledu hrádku Stř́lišstě-Radonín. Radonín zmiňovaný k roku 1224 leží severovýchodně pod vrchem, na kterém je situován hrádek, pod nímž vedou relikty úvozových cest lesem, jenž stále nese označení Královský les. Dalším obdobně formovaným opevněním se sídelní funkcí byl stonařovský Hirschhübel (Plaček 2001, 591; Měřínský 1977, 38-40). Sídla v Kněžicích, ve Střížově nebo Vílanci a jinde při kostelech nelze prozatím identifikovat. O tom, kde sídla stála, lze prozatím jen spekulovat na základě výpovědi kartografických pramenů a charakteru analogických šlechtických sídel z první poloviny 13. století s vazbou na církevní stavbu. Pro kněžický sídelní prostor je možná rekonstrukce původního panského sídla při kostele sv. Jakuba s následným přesunem kvůli formování proboštství na místo zámečku na jižním okraji Kněžic. Druhou možností je přímo zřízení sídla v místě současného zámečku. Na mapách I. vojenského mapování je celkem podrobně zobrazen půdorys Kněžic, kde na východní straně půdorysu tzv. silnicovky mezi kostelem a jeho severní zástavbou je výrazná nezastavěná proluka v délce několika desítek metrů. K jejímu zastavění došlo postupně, jednu z fází zachytila indikační skica z roku 1835, kde je uváděno kostelní zboží na parcelách č. 134 a 135. Hřbitov je uváděn jako parcela č. 137. Fara nese číslo popisné 46 a sad se rozkládá na parcele 136. Tento úsek mohl vytvářet původní majetkový komplex pro umístění proboštství uváděného po polovině 13. století, a proto bychom mohli hledat sídlo pánů z Kněžic někde jižně od kostela. Šlechtické sídlo přestavěné v zámek v 16. století a barokizované Collalty v 18. století, s klasicistní úpravou z počátku 19. století v současné době funguje jako obecní úrad, má popisné číslo 1 a obdobně jako u Stonařova by vytvářelo opevněný prvek poměrně vzdálený od kostela (Samek 1999, 145). Místním geomorfologickým poměrům by primárně vyhovovalo místo v blízkosti kostela nebo parcela stávajícího zámečku čp. 1. Hypoteticky lze připustit obě možnosti. Písemné prameny prokazují osídlení v místě zámečku již v průběhu 14. století, ale prozatím nedisponujeme archeologickými daty, která by potvrdila první nebo druhou možnost.

\section{Panství Rokštejn}

Ve srovnání s okolními šlechtickými panstvími na jediném rokštejnském stál kamenný hrad, i když jeho podoba ještě ve 13. století mohla konfigurací terénu připomínat zemní opevnění jako na Radoníně, jeho stavbu ovlivnilo místní skalnaté podloží a následné využití 
vylámaného kamene na stavbu opevnění. Samotná existence a přestavby kamenného hradu poukazují na výraznou hospodářskou i politickou moc v regionu. Hospodářská stabilita a prosperita panství souvisí s provozem jeho centra a záměry vlastníka. Změny ve struktuře panství, přikupování, nebo naopak prodej sídel a jejich zánik mírně odhalují ekonomické faktory, které vedle písemně zaznamenaných politických tendencí s možným válečným vyústěním silně ovlivňovaly v kontrastu s mírou úživnosti chod samotného panství. Míra úživnosti je jednou ze zásadních otázek hospodářského chodu panství a jeho jednotlivých jednotek v podobě vesnických sídel se zemědělským zázemím, nastupujícím rybníkářstvím a možnou těžbou jakýchkoliv dostupných surovin. Výrazné zaměření na zemědělství, rybníkářství a těžbu dřeva prokazují zápisy v urbářích brtnického panství z průběhu 16. století (MZA, fond G 10, inv. č. 638; MZA, fond G 169, č. I. 2561; 2562). Velikost panství v jeho počátcích neprokazuje zásadní vazbu na těžbu stř́bra a základní chod se opíral patrně jen o vesnické osídlení se zemědělstvím (Hrazdil a kol. 2012).

Opora v písemných pramenech je mizivá a náhlá existence hradu téměř překvapující. Vývoj panství prošel přes šlechtické a zeměpanské fáze zpět k šlechtickému držení hradu. Vojenská likvidace Rokštejna jako nebezpečného centra nebyla ekonomickou zkázou pro panství, při vojenské akci nezahynul nikdo $\mathrm{z}$ valdštejnského rodu a zároveň mohli Valdštejnové přesídlit na hrad v Brtnici s městečkem a své panství řídit odtud.

Územní rozloha panství představuje několik základních vývojových stadií (obr. 6). Existence prvotního panství s centrem ve Střížově, odkud došlo k založení hradu Rokštejna, je rekonstruována podle několika faktů. Ve vsi stojí kostel sv. Jana Křtitele s polygonálním závěrem, výstavbou lodě se hlásí do poloviny 13. století a má náležet k přechodním stavbám. Tomu odpovídá i nalezená tuhová keramika $\mathrm{v}$ jeho blízkosti, přesněji za východní ohradní zdí původního hřbitova ve výkopu pro elektrické sítě (duben 2016). Nalezená keramika se svým charakterem hlásí do 13. století. Presbytář podle charakteru kleneb náleží až třetí čtvrtině 14. století. D. Líbal počítá s dokončením střížovského kostela v první polovině 14. století, i když okna mají charakter 13. století. Platby za stavbu ve Střižově a transakce s desátkem v Komárovicích dovolují klást stavbu presbytář́e do doby kolem roku 1367 (Líbal 2001, 471; Richter 1952, 232; Vohryzek 2012, 70). Výstavbou kamenného hradu se Ruthenštejni/Stř́žovici jako jediný ze šlechtických rodů posunuli v reprezentativní formě o řád výše než okolní šlechta. Markraběcí zisk hradu Rokštejn a jeho zázemí uvedl do pramenů druhé poloviny 14. století markrabě Jan Jindřich a odkazoval se na koupi hradu v roce 1366 (CDM IV, 323-325 č. 420; Vohryzek 2013, 68).

1. Centrum Rokštejn (1289-1339/1359) - Ruthenštejni; majetky: Komárovice, Stř́ížov, Přímělkov, půl Smrčného, Panská Lhota (ZDB VI, 131 č. 343)

2. Centrum Rokštejn (1339/1359-1398/1399) - markrabě moravský; majetky: Jestřebí, Malé, Uhřínovice, Lhota (Panská Lhota), Smrčné, Přibyslavice, Čáslavice, Petrovice, Číchov, Okř́ŕšky, Ř́mov, Slavice a Stařeč (ZDB VI, 98-101 č. 4)

3. Centrum Brtnice-Rokštejn (1398/1399 - 1451/1467) - Valdštejnové; majetky: Brtnice s městečkem, Jestřebí, pustá Lhotka, Uhřínovice, Lhota, Malé, Stř̌žzov, Přímělkov, Smrčné, kostelní podací v Čáslavicích a Rokštejn (AČ IX, 273 č. 32)

4. Centrum Brtnice (1451/1467-1623) - Valdštejnové; majetky: Brtnice, Trhová, Kněžice, Opatov, Stará Říše, Malé Brtničky, Jestřebí, Uhřínovice, Komárovice, Střížov, Malý, Lhota, Smrčný, Bransouze, Chlum, Číchov, Radonín, Rychlov, Víska, Brodce, Hrutov, Předín, Heraltice, Zašovice, Petrovice, Krahulov, Čechočovice, Krahulov, Hvězdoňovice, Chlístov, Štěměchy, Čáslavice, Př́imělkov (MZA, fond G 10, inv. č. 638, fol. 1-84)

Existenci rokštejnského panství a hradu Rokštejna písemně potvrzuje až listina z roku 1289 , ve které vystupuje za třebíčským, želivským a zábrdovickým opatem jistý Ruthonis de Ruthenstein. Po něm následují měšt’ané Jihlavy, listinu dále jako svědci potvrzují Bernhardo 

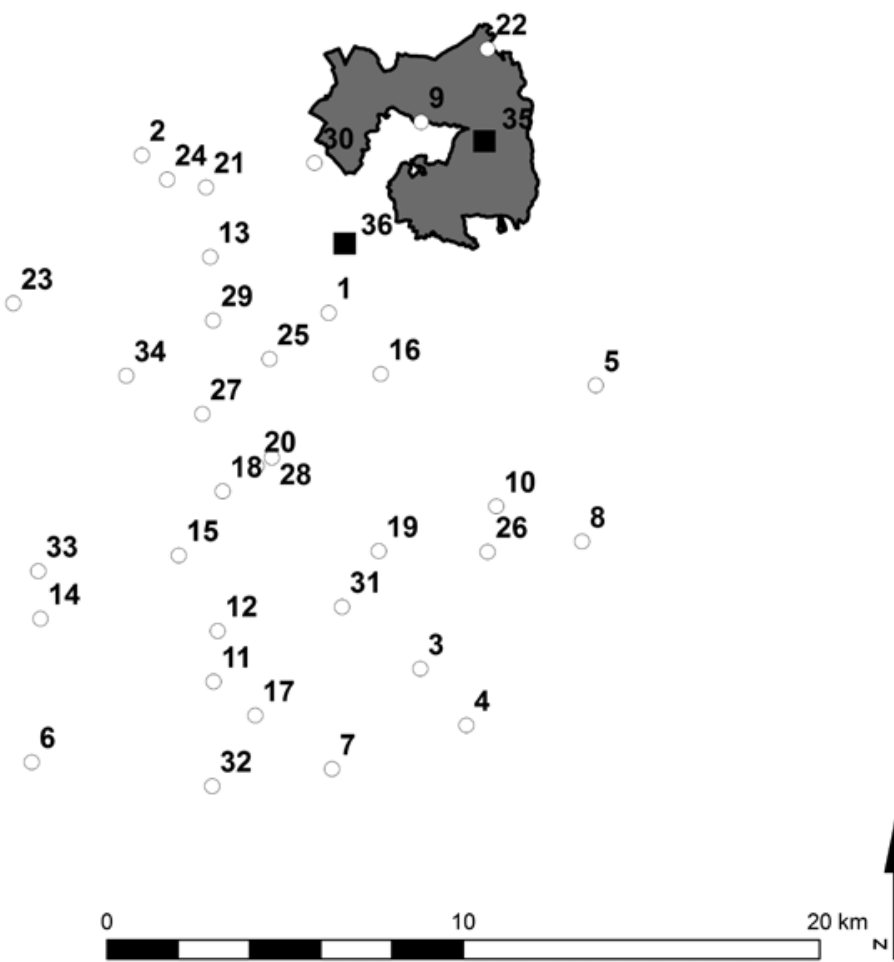

Obr. 6. Ruthenštejnské panství na konci 13. a v první polovině 14. století. 1 - Brtnice-Bukovec (Kněžice-Čihadla), 2 - Pod Suchou - mlýn, 3 - Bezděkov, 4 - Březová, 5 - Čertovec, 6 - Čížov, 7 - Dašovice, 8 - Dobrkovice, 9 - Doubkov, 10 - Hofeřice, 11 - Jeníšov I, 12 - Jeníšov II, 13 - Lhota/Lhotka, 14 - Lipolec, 15 - Loučky, 16 - Malé Petrůvky, 17 - Malý Štítek, 18 - Martinice, 19 - Mosty, 20 - Opatov-Červené Žlíbky, 21 - Ostejkovice, 22 - Ozřetín, 23 - Pfaffendorf, 24 - Regenholz, 25 - Šamonín, 26 - Skalky, 27 - Služanov, 28 - Stančice, 29 - Strážov, 30 - Střenčí, 31 - Velké Petrůvky, 32 - Velký Štítek, 33 - Veselí/Veselá, 34 - Zhořec, 35 - Rokštejn, 36 - Brtnice, 37 - Jihlava.

Abb. 6. Herrschaft Ruthenstein zum Ende des 13. und in der ersten Hälfte des 14. Jahrhunderts. 1 - Brtnice-Bukovec (Kněžice-Čihadla), 2 - Pod Suchou - Mühle, 3 - Bezděkov, 4 - Březová, 5 - Čertovec, 6 - Čížov, 7 - Dašovice, 8 - Dobrkovice, 9 - Doubkov, 10 - Hofeřice, 11 - Jeníšov I, 12 - Jeníšov II, 13 - Lhota/Lhotka, 14 - Lipolec, 15 - Loučky, 16 - Malé Petrůvky, 17 - Malý Štítek, 18 - Martinice, 19 - Mosty, 20 - Opatov-Červené Žlíbky, 21 - Ostejkovice, 22 - Ozřetín, 23 - Pfaffendorf, 24 - Regenholz, 25 - Šamonín, 26 - Skalky, 27 - Služanov, 28 - Stančice, 29 - Strážov, 30 - Střenčí, 31 - Velké Petrůvky, 32 - Velký Štítek, 33 - Veselí/Veselá, 34 - Zhořec, 35 - Rokštejn, 36 - Brtnice, 37 - Jihlava.

de Ruthensteine et fratribus suius Zdislao et Wyrschone (Bernhard z Ruthensteina a jeho bratři Zdislav a Vrš). Z bratrů se jen Bernhard píše po hradě. Listina samotná je vydána Theodorichem z Kněžic, který touto formou uděluje patronátní právo nad kostely v Opatově a v Moravanech knězi Jindřichovi a premonstrátům v Želivě. Rutho přivěsil k listině i svou pečet', která nese obraz leknínového listu beze stopky s neúplným opisem /VThC R///?nSTEIn (CDM VII/3, 776-777 č. 147; Sedláček 2003, 293, tab. 79:5). Opis obsahoval patrně formu jména a predikátu 
bez předložky Rutho Ruthonstein nebo Ruth D. Ruthonstein. Otázkou zůstává, zda shoda jmen v podobě Rutho pánů z Kněžic a pánů z Rokštejna znamená př́ibuzenství. Díky archeologickému svědectví víme, že hrad zanikl poprvé před rokem 1306/1307, ale jeho majitelé jej dokázali obnovit a architektonicky výrazně vylepšit (Mazáčková-Lisá 2016, 80-82).

Panství s primárním centrem ve Střížově a následným druhým centrem v podobě kamenného hradu Rokštejna, který stojí na levém břehu Brtnice v části jejího dolního toku, zahrnovalo Stř́ižov včetně patronátního práva ke kostelu, Přímělkov, Komárovice (patrně jen část, staly se sporným majetkem ve 14. století; ZDB VI, 131 č. 544), polovinu Smrčného a Ozřetín (ZDB VI, 131 č. 543). Písemné prameny, které uvádí statky Stř́žoviců v druhé polovině 14. století, nereflektují stav ještě v době vlastnictví hradu do období 1339-1359 (RTT I, č. 409; CDM IX, 103 č. 127; Mazáčková 2012, 146).

Střižovské panství se rozkládalo na severní levobřežní terase řeky Brtnice (Komárovice, Střížov, Ozřetín, Přímělkov) s přesahem na pravou stranu v povodí Jihlavy, kde k panství náležela polovina Smrčného a Panská Lhota, v níž je k roku 1444 uváděn poplužní dvůr (AČ IX, 273 č. 32). Z vesnic zanikl jen Ozřetín, který se později ve 14. století označuje jako dvůr a nakonec mizí z pramenů úplně. Jeho jméno lze dohledat jen v indikační skice Střížova a Přímělkova jako trat' v předním a zadním Ožretíně.

Sporným zůstává vlastnictví Malého a Panské Lhoty, uváděných až v roce 1437 (ZDB XII, 338 č. 181). Panská Lhota náležela ke kostelu ve Stř́žově, a patrně spolu s hradem se dostala do majetků markraběte Jana Jindřicha. Rokštejn se dostává do markraběcích majetků kolem poloviny 14. století a patrně z nich až do svého zániku oficiálně nemizí, protože jediná osoba, která kdy vložila hrad do zemských desk, Rokštejn i Brtnici, je markrabě Jan Jindřich (ZDB VI, 98-101 č. 4). Valdštejnové jsou s hradem spojováni již kolem roku 1399, protože v okolí skupují majetky, ale hrad není jen jejich držbou. Dělí se o něj ještě s jinými rody (Vohryzek 2013, 84-85; Mazáčková 2012, 159-165). V držbě nakonec vítězí a hrad si nechávají jako majetek potvrzovat (AČ VII, 579 č. 23).

Markrabě ve svých testamentech definuje druhý rozsah panství. Oproti základu vzniklému ze zeměpanského brtnického majetku, jako byly Jestřebí, Malé a Uhřínovice, připojil k hradu Lhotu a Smrčné, původně součást ruthenštejnských majetků, dále Přibyslavice, Čáslavice, Petrovice, Č́íchov, Okř́išky, Římov, Slavice a Stařeč. Samostatně je zmíněna Brtnice jako městečko s mýtem a soudem (ZDB VI, 98-101 č. 4). V druhé polovině 14. století se původní rokštejnské panství rozdělilo mezi původní vlastníky, kteří se píší ze Střížova a následně prodávají části svého panství, jež se dostanou až do majetku Valdštejnů v roce 1399 (ZDB VIII, 229 č. 238). Valdštejnové kupují jen Stř́ižov s patronátním právem, Přímělkov a polovinu Smrčného. Majetek ve Stř́žově si udržuje rodina předchozího vlastníka Jana z Meziř́ičí, a to Mikuláš z Křižanova s majetkem o velikosti jednoho lánu. Mikuláši náleží ještě dvůr v Ozřetíně, který nebyl předmětem prodeje Valdštejnům a objevuje se v majetku původních Střížovců (ZDB VII, 183 č. 591; ZDB IX, 262 č. 170). Až v roce 1415 zapisuje druhý z rodu Valdštejnů sídlící v regionu majetky své manželce Anně, lze mezi nimi opět pozorovat pouze koupi z roku 1399 (Střížov, Přímělkov a půl Smrčného), doplněnou o Bransouze a majetky náležící k hradu Sádek (ZDB XI, 300 č. 188). Zdeněk z Valdštejna v roce 1437 jako první zapisuje platy z vesnic Lhota se dvorem, Malé a StříŽov (ZDB XII, 338 č. 181).

Ke spojení původních majetků Brtnice a Rokštejna došlo až za Valdštejnů, ale ani Brtnice ani Rokštejn nevystupují v tomto období v zemských deskách jako alodiální zboží a Zdeněk se v deskách uvádí s predikátem ze Sádku, který má jako alod (ZDB XII, 338 č. 181). Rokštejn přešel na Valdštejny jako zástavní zboží za dluh markraběte Prokopa a nadále se obstarávají potvrzovací listiny (AČ VII, 579 č. 23). Ve druhém desetiletí 15. století již rokštejnské a brtnické panství spravovali Valdštejnové sami. Hrad stojí na skalním ostrohu nad řekou Brtnicí. Valdštejnové jej získali již v přsestavěné podobě se dvěma paláci a dvěma věžemi a severním předhradím. Jejich nejméně půlstoletí trvající vláda nad hradem mu vtiskla další stavební podobu a poměrně výraznou přeměnu struktury hradu, která ale nedokázala hrad ochránit před 
centrálni sidla

markraběci panstvi Rokštejn

W/2, markrabéci panstvi Brtnice

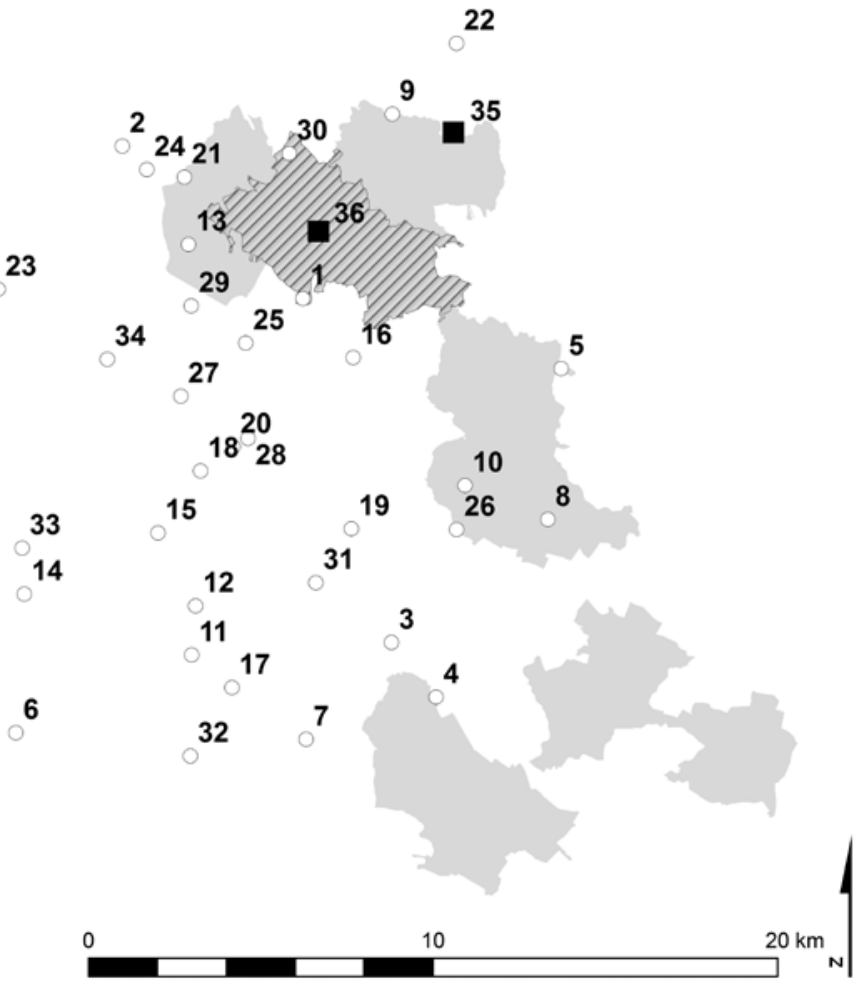

Obr. 7. Markraběcí majetky ve druhé polovině 14. století. 1 - Brtnice-Bukovec (Kněžice-Čihadla), 2 - Pod Suchou - mlýn, 3 - Bezděkov, 4 - Březová, 5 - Čertovec, 6 - Čížov, 7 - Dašovice, 8 - Dobrkovice, 9 - Doubkov, 10 - Hofeřice, 11 - Jeníšov I, 12 - Jeníšov II, 13 - Lhota/Lhotka, 14 - Lipolec, 15 - Loučky, 16 - Malé Petrůvky, 17 - Malý Štítek, 18 - Martinice, 19 Mosty, 20 - Opatov-Červené Žlíbky, 21 - Ostejkovice, 22 - Ozřetín, 23 - Pfaffendorf, 24 - Regenholz, 25 - Šamonín, 26 Skalky, 27 - Služanov, 28 - Stančice, 29 - Strážov, 30 - Střenčí, 31 - Velké Petrůvky, 32 - Velký Štítek, 33 - Veselí/Veselá, 34 - Zhořec, 35 - Rokštejn, 36 - Brtnice, 37 - Jihlava.

Abb. 7. Markgräfliche Besitztümer in der zweiten Hälfte des 14. Jahrhunderts. 1 - Brtnice-Bukovec (Kněžice-Čihadla), 2 - Pod Suchou - Mühle, 3 - Bezděkov, 4 - Březová, 5 - Čertovec, 6 - Čížov, 7 - Dašovice, 8 - Dobrkovice, 9 - Doubkov, 10 Hofeřice, 11 - Jeníšov I, 12 - Jeníšov II, 13 - Lhota/Lhotka, 14 - Lipolec, 15 - Loučky, 16 - Malé Petrůvky, 17 - Malý Štítek, 18 - Martinice, 19 - Mosty, 20 - Opatov-Červené Žlíbky, 21 - Ostejkovice, 22 - Ozřetín, 23 - Pfaffendorf, 24 - Regenholz, 25 - Šamonín, 26 - Skalky, 27 - Služanov, 28 - Stančice, 29 - Strážov, 30 - Střenčí, 31 - Velké Petrůvky, 32 - Velký Štítek, 33 - Veselí/Veselá, 34 - Zhořec, 35 - Rokštejn, 36 - Brtnice, 37 - Jihlava.

vojenským zásahem, jenž ukončil jeho existenci. Valdštejnové nepřestavovali hrad jako pevnost, jeho nevýhodná poloha v údolí k tomu ani nevybízela.

Pád center může ovlivnit i zanikání jejich ekonomického zázemí. V případě vojenského zásahu proti hradu Rokštejnu lze počítat minimálně se zánikem poplužního dvora v Panské Lhotě. 
Rekonstrukce samotného pádu hradu se vyvozuje ze zjištěné archeologické situace a dostupných písemných pramenů. Vojenský zánik dokreslují dvě obléhací polohy jižně ve svahu od hradu a požárové vrstvy s destrukcí s výskytem militarií (Mazáčková 2011; 2012, 192-421). Doba zániku se od počátku bádání o historickém vývoji Rokštejna různě posunovala. Nejstarší vlastivědná literatura uváděla česko-uherské války a rok 1468, Z. Měřínský datoval zánik hradu do husitských válek a jeho částečné obnovení kolem poloviny 15. století (Měřínský 2007, 55; Mazáčková 2012, 75-78). Přehodnocení archeologické situace i písemných pramenů pokládá zánik do období před rokem 1468, patrně do druhé poloviny nebo druhé třetiny roku 1467 po sklizni. Roku 1464 pohání Jan z Valdštejna a ze Slavkova Mikuláše z Petrovic o 300 kop grošů z Okříšek a Petrovic, že „neosazuje službou k hradu Rokštejnu dvěma koňma“ (LCS IV, 154 č. 773). O Rokštejně mluví dokonce sám král Jiří z Poděbrad v roce $1465 \mathrm{v}$ listě, který zaslal Jihlavským. Jiří v něm omlouvá a brání Hynka z Valdštejna, že zloděj vyslýchaný na mučení v Telči křivě vypověděl o hradě Rokštejně (Regesten, 32 č. 169; Městská správa Jihlava, 52 č. 165). Poté král chrání Hynka a Václava z Valdštejna před Jihlavskými ještě jednou v roce 1467, když listem sepsaným 26. května žádá purkmistra a konšely, aby nepodporovali nepřátele bratří z Valdštejna, kteří stojí věrně při králi (Regesten, 33 č. 179; Městská správa Jihlava, 54 č. 173). Vyhrocená situace v regionu proti sobě postavila letité odpůrce katolíky a kališníky. Valdštejnové jako kališníci stáli proti katolické Jihlavě, odpůrce krále získal původní valdštejnské zboží Sádek. Král dopomohl za věrné služby při obléhání Cornštejna (1464-1465) Jindřichovi Mládenci z Miličína $\mathrm{k}$ majetkům jižně od rokštejnsko-brtnického panství a díky tomu vytvořil kompaktnější územní útvar, který mu zachovával podporu. I když se Valdštejnové proti Jiř́iho darům odvolali, kališnický vliv v regionu proti pánům z Hradce a Zdeňkovi ze Šternberka byl výrazný. Zápis z městské knihy jihlavské, která vynechala hrad Rokštejn jako odbojný hrad, patrně poukazuje na jeho zánik někdy v druhé polovině roku 1467 (Městská správa Jihlava, 54 č. 175; Zaoralová 1988, 105; Mazáčková 2012, 188). Strategické obsazení sádeckého hradu s panstvím Zdeňkem ze Šternberka vrazilo zásadní mocenský klín do zad Valdštejnům stojícím proti Jihlavě. Zdeněk ze Šternberka přistoupil ke smlouvě stvrzené roku 1467. Po pádu Rokštejna Valdštejnové natrvalo přesídlili na hrad v Brtnici, který postupně zvelebovali až v renesanční zámek. Jejich aktivity ukončila Bílá hora, která znamenala pro celé panství radikální změnu v ekonomické i sídelní strategii.

Druhým centrem dobytým v roce 1468 byla tvrz ve Štěměchách. Do panství jižně od brtnického a od jihu sevřeného sádeckým přišel v roce 1464 Oldřich Mládenec z Miličína, který koupil od Přemka, knížete těšínského, tvrz, dvůr a ves Štěměchy s dílem vsi Předína. Královskou odměnou bylo Oldřichovi povýšení do panského stavu (ZDB XIII, 395 č. 26; ZDB XV, 4 č. 2). Oldřich získal od krále majetky v Zašovicích, Předíně, Dašovicích a Svojkovicích a patrně si je vojensky odsloužil při obléhání Cornštejna (LCS IV/1, 101 č. 431-435; LCS IV/1, 193 č. 196; LCS V, 49 č. 265; LCS V, 337 č. 407). Majetky v Předíně, Heralticích, Zašovicích, Bransouzích, Chlístově a Hvězdonicích, celá ves Čížov, pusté vsi Vacenovice, Svojkovice, Jeníšov, Petrůvky, Bezděkov, Březová a Regenholz byly rodu zapsány do zemských desk až v roce 1490 králem Vladislavem, ale s poznámkou o jejich nabytí v roce 1466 (ZDB XVI, 48 č. 135). Právě Regenholz je podle poznámky editora do pramene připsán na okraj zápisu jinou rukou a i jiným inkoustem ve formě Rygnholcz (ZDB XVI, 48 č. 135). A zároveň jediný Regenholz nezapadá územně do králova daru a vytváří jedinou lokalitu, navíc již zaniklou nad hranicí brtnicko-rokštejnského panství vysunutou směrem k Jihlavě. Oldřich stál věrně při králi Jiřím, stejně jako Valdštejnové, a to se stalo důvodem pro dobytí Štěměch hradeckými vojsky. Sám Oldřich padl v bojích v Třebíči roku 1468. Až v roce 1486 byly Štěměchy podle jihlavských úmluv vráceny pánům z Miličína. Oldřich Mládenec z Miličína prodal Štěměchy a další majetky Zdeňkovi a Burianovi z Valdštejna v roce 1505 (AČ X, 293 č. LVI). Valdštejny zakoupený majetek čítal Štěměchy (tvrz, dvůr a ves s mlýnem), Předín, šest lánů a dva podsedky v Heralticích, v Zašovicích tři a čtvrt lánu, $v$ Bransouzích pět lánů s podsedkem s mlýništěm a řekou, v Hvězdoňovicích dvưr s lánem a s mlýnem, v Chlístově tři lány, pusté vsi Petrůvky, Březovou, Bezděkovec, Dašovice, Svojkovice, Jeníšov, Čížov. Ale zaniklou ves Vacenovice s dvory prodává Oldřich 
centrálni sidla

valdštejsnké koupě $\mathrm{kr}$ r. 1399

valdštejnská držba markraběcího panstvi Rokštejn

DID valdštejnská držba markraběciho panstvi Brtnice

23

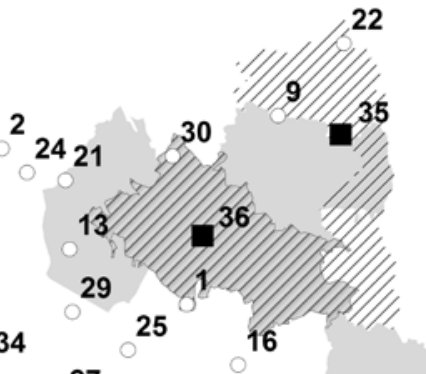

27

20

1828

15

$19 \quad \begin{array}{ll}10 & \\ 26 & 8\end{array}$

33

14

12

31

11

17

6

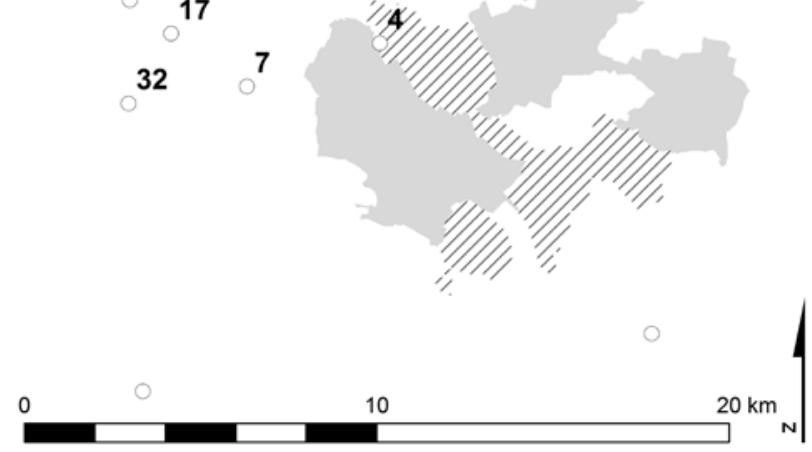

Obr. 8. Valdštejnské panství na počátku 15. století. 1 - Brtnice-Bukovec (Kněžice-Čihadla), 2 - Pod Suchou - mlýn, 3 - Bezděkov, 4 - Březová, 5 - Čertovec, 6 - Čížov, 7 - Dašovice, 8 - Dobrkovice, 9 - Doubkov, 10 - Hofeřice, 11 - Jeníšov I, 12 Jeníšov II, 13 - Lhota/Lhotka, 14 - Lipolec, 15 - Loučky, 16 - Malé Petrůvky, 17 - Malý Štítek, 18 - Martinice, 19 - Mosty, 20 - Opatov-Červené Žlíbky, 21 - Ostejkovice, 22 - Ozř̌tín, 23 - Pfaffendorf, 24 - Regenholz, 25 - Šamonín, 26 - Skalky, 27 - Služanov, 28 - Stančice, 29 - Strážov, 30 - Střenčí, 31 - Velké Petrůvky, 32 - Velký Štítek, 33 - Veselí/Veselá, 34 - Zhořec, 35 - Rokštejn, 36 - Brtnice, 37 - Jihlava.

Abb. 8. Grundherrschaft Waldstein zu Beginn des 15. Jahrhunderts. 1 - Brtnice-Bukovec (Kněžice-Čihadla), 2 - Pod Suchou - Mühle, 3 - Bezděkov, 4 - Březová, 5 - Čertovec, 6 - Čížov, 7 - Dašovice, 8 - Dobrkovice, 9 - Doubkov, 10 - Hofeřice, 11 - Jeníšov I, 12 - Jeníšov II, 13 - Lhota/Lhotka, 14 - Lipolec, 15 - Loučky, 16 - Malé Petrůvky, 17 - Malý Štítek, 18 - Martinice, 19 - Mosty, 20 - Opatov-Červené Žlíbky, 21 - Ostejkovice, 22 - Ozřetín, 23 - Pfaffendorf, 24 - Regenholz, 25 - Šamonín, 26 - Skalky, 27 - Služanov, 28 - Stančice, 29 - Strážov, 30 - Střenčí, 31 - Velké Petrůvky, 32 - Velký Štítek, 33 - Veselí/ Veselá, 34 - Zhořec, 35 - Rokštejn, 36 - Brtnice, 37 - Jihlava. 
Mládenec z Miličína Hankovi ze Zap. Další v roce 1490 připsaná zaniklá ves Regenholz se mezi majetkem prodaným Valdštejnům neobjevuje (ZDB XVII, 119 č. 215, 217).

\section{Zanikání vesnických sídel}

Hledání důvodu zániku v písemných pramenech se omezuje na písemnosti majetkoprávní a soudní povahy - zemské desky, knihy půhonné nebo městské knihy jihlavské. Změny majitelů panství, výpis jednotlivých sídel a v některých prrípadech zdůraznění zaniklých sídel vypovídají o situaci k danému vročení zprávy. Žádný majetkový převod neuvádí důvod zániku sídla. Charakter vlastníka, majetková nebo politická situace ukazují míru stability v regionu. Malá panství 14. století a jednotlivé svobodné dvory se nakonec dostávají do majetků rodů, které se zaměřily na územní celistvost a na zemské úrovni zastávají poměrně důležité funkce. Proto lze důvody zániku hledat v terénní dispozici lokality, ekonomickém zaměření, ale zároveň i v ambicích vlastníka.

Nastíněný vývoj několika základních panství vzniklých ve 13. století ve zkoumaném regionu (panství Markvarta z Hrádku, pánů z Heraltic, Ranožírovců, Hrutovců z Kněžic) ukazuje, že v průběhu 15. až do počátku 16. století se panství pomalu a systematicky dostávala do vlastnictví Valdštejnů. Valdštejnská ekonomika se snažila vytvořit kompaktní území se správním centrem. Zaměřila se přitom na zemědělství a systematické přerozdělení území zaniklých vsí pro zemědělskou činnost, stejně jako zakládání rybníků s chovem ryb.

Zaniklé vesnice na původních panstvích Markvarta z Hrádku a pánů z Heraltic byly výrazně poznamenány těžbou zlata. Zajímavý je zápis $\mathrm{v}$ půhonech o placení desátku ze zaniklých Svojkovic uváděných již roku 1257, které si nárokuje probošt kláštera v Nové Říši. Platba svědčí bud' o zemědělském využívání půdního fondu patrně bez vazby na osídlení intravilánu vesnice, nebo se naopak jedná o pokus vymoci desátek z majetku nového vlastníka (LCS IV/1, 228 č. 1007). Druhým případem uváděným již v roce 1234 mohou být Ostejkovice, původně zeměpanský majetek patřící k Brtnici, který se ale neobjevuje v testamentu Jana Jindřicha (CDB III, 97 č. 88; ZDB VI, 98-101 č. 4). Existenci Ostejkovic lze historicky vložit mezi léta 1234-1371. Vesnice se neuvádí jako pustá v písemných pramenech. Zato její archeologická evidence na základě terénní prospekce a zachycení jejích stop v rámci skenování krajiny zakonzervovala její původní formu plužiny navazující na intravilán. Jedná se o klínovou plužinu, kterou lze přes indikační skicu Uhř́novic z roku 1835 také identifikovat v rozměření lesních parcel. Samotné Uhřínovice, zmíněné poprvé v roce 1234, však zároveň v testamentu Jana Jindřicha z roku 1371 měly původně také klínovou plužinu, její mezní pásy zachycuje nejen indikační skica, ale i vyprahlostní porostové př́znaky na ortofotu z roku 2014/2015 dostupném na na serveru mapy.cz. Vedle Uhřínovic je dalším případem klínové plužiny napojené na intravilán při stejné evidenci v písemných a kartografických pramenech i Jestřebí (CDB III, 97 č. 88; ZDB VI, 98-101 č. 4).

Zaniklé vsi uváděné před vypuknutím česko-uherských válek jsou jen Ozřetín, Lhotka, částečně Střenčí a Svojkovice (tab. 1). Zánik osídlení vojenskou akcí lze doložit na Stančicích, pozvolný úpadek převrstvený druhotným zemědělským využíváním na Střenčí. Tyto závěry podrobné povrchové prospekce vypovídají jen o zlomku zaniklých vsí. Z původně rokštejnského panství postupně zanikal v souvislosti s úpadkem rodu Ozřetín. Valdštejnové ke svému panství v roce 1399 přikupují zaniklou Lhotku a až v 15. století se dostali nejdříve k protiprávnímu a následně zlegalizovanému držení dvou zanikajících vesnic Střenčí a Stančice, zbylé vesnice získali již zaniklé. Podobně je tomu s protiprávním držením Lhoty Čertovce, která se uvádí jako pustá v roce 1499, ale ještě osedlá v roce 1481. Ta se do majetku Valdštejnů dostává až v druhé polovině 16. století (LCS V, 347 č. 465; LCS VII, 177 č. 886; Nekuda 1961, 91). Část Dašovic mohla existovat ještě v roce 1490 (ZDB XVI, 38 č. 55), i když se o dva roky později s odkazem k roku 1466 uvádějí jako pusté. Obdobně se projevuje v písemných pramenech Střenčí. Část valdštejnská je v roce 1466 uváděna jako pustá, přesto Barbora z Třebíče prodává Valdštejnům dvůr ještě v roce 1495. Válečné události mohly ovlivnit jen Stančice. Výrazný požárový horizont je poměrně výmluvný, stejně jako př́ítomnost militarií (hroty střel). Pokud zohledníme fakt, že soupis 
zaniklých vsí získaných Oldřichem Mládencem z Miličína odpovídal skutečnosti již v roce 1466, jak dokládají zápisy o Svojkovicích, je potřebné přehodnotit situaci o vlivu česko-uherských válek na zanikání osad na Brtnicku, jak nastínila M. Zaoralová (1988, 104-105), a po provedení terénní prospekce stanovit druhy zanikání a proběhlé depoziční i postdepoziční procesy. Zaniklé vesnice uvedené v urbáři brtnického panství z roku 1538 byly druhotně zemědělsky využivány. Jejich vyměřený půdní fond byl rozdělen mezi hospodáře z okolních existujících sídel a zemědělská činnost pokračovala i dalších 150 let po zániku původního osídlení. Doložená těžba drahých kovů, provázaná např́iklad s Dašovicemi, se v urbáři neprojevuje. $\mathrm{V}$ druhém případě soupis zaniklých vesnic Oldřicha Mládence z Miličína zobrazuje stav až z roku 1492, a česko-uherské války mohly významně zasáhnout do existence nebo prosperity lokalit. Problematické budou osady s doloženým postupným zanikáním, jako jsou Dašovice.

\section{Závěr}

Pro rekonstrukci osídlení panství Brtnice v hranicích udávaných urbářem k roku 1538 (MZA, fond G 10, inv. č. 638) je důležitý předchozí historický vývoj a prozatím zjištěné ekonomiky sídel vesnického charakteru. Základní složkou vesnické ekonomiky je zemědělství, které se i nadále projevilo při rozdělování půdy hospodářům z okolních sídel na zemědělském zázemí zaniklých vsí. Přesto se v okolí nebo přímo v okruhu zemědělského zázemí zaniklých sídel objevují doklady těžby drahých kovů. Historická konstrukce osídlení a změny majitelů dovolují nahlédnout do možného komplexu ekonomik a jejich vývoje u zaniklých sídel.

Na základě výpovědi písemných pramenů lze rekonstruovat několik základních horizontů vymizení sídel nebo naopak nástupu zmínek o zaniklých sídlech. První horizont zahrnuje výpis darovaných existujících sídel klášterům v Třebíči a Louce u Znojma ve 12. století. Ve 13. století, a to především ve 30. letech, se objevují výpisy sídel jako majetků různých vlastníků nebo desátkových vsí kostelů v Přibyslavicích, Jihlavě a Brtnici, zde zmíněná sídla mnohdy nelze identifikovat kvůli uvedené písemné podobě a jejich zasazení nebo spojení se stávajícími sídly je více než problematické (naposledy souhrnně Mazáčková 2012, 130-131, tab. 13). V průběhu 12. a 13. století vznikala v jihovýchodním podhưří, ale i v rámci centrální Českomoravské vrchoviny sít' sídel, jejichž část nemá návaznost na mladší osídlení zemědělského charakteru ve 14. století.

Od 14. století (1399, Lhotka) se objevují zápisy v zemských deskách o zaniklých sídlech, jejich převodech a kodifikování jako zaniklého sídla převáděného na různé vlastníky. Jedná se o řádně územně vymezené ekonomické zázemí vesnic, i když zaniklých, které nebylo přerozděleno a nerozmělnilo se mezi okolní sídla (viz zaniklé Ostejkovice), ale díky vyměření byly možné další majetkové transakce s tímto územím a jeho následné zemědělské využívání. Označení pusté - deserta - uvádí u sídel zemské desky a knihy půhonné. Tato praktika př̌šla i do urbářů brtnického panství vzniklých v průběhu 16. století, které udržovaly nejen název vesnice, ale i její původní vyměření. Majitelé zaniklého sídla dále pracují a nechávají přerozdělovat jeho zázemí na obdělávané části zákopy, úhory (auleghle = úlehle), luka, zátočky a jiné kusy obdělávané nebo neobdělávané půdy včetně lesa za trvalé platy. Výše platů za pronájem zákopů (dílů zemědělské půdy různé velikosti, možná i kvality) kolísá. Pronájem hospodářù z okolních sídel na panství doplňovaly i osoby mimo panství Brtnice, např́iklad ze Stonařova nebo Dlouhé Brtnice. V případě zaniklého Střenčí se jedná o osedlé z Jestřebí, Brtnice, Kněžice, Vísky, Brtničky, Malé Brtnice, Dlouhé Brtnice a Stonařova (MZA, fond G 10, inv. č. 638, fol. 109-113).

Zahrnutí zaniklé vesnice s plužinou do katastru jiného sídla, pohlcení jeho ekonomickým zázemím (napřs. Jestřebí u Brtnice) máme dokumentováno až se vznikem indikačních skic ve 30. letech 19. století v návaznosti na změnu ve vývoji ekonomiky panství a zalesňování prostor s tímto typem zemědělské půdy.

O druzích a prŕčinách zániku vesnického osídlení písemné prameny nevypovídají. Jen u míst s centrální funkcí je uveden způsob zániku, např́iklad vojenským přepadem jako v případě Štěměch kolem roku 1409 nebo 1468 (LCS II, 168 č. 674). V historických analýzách nebo 
interpretacích archeologických situací jsou zániky spojeny s neklidným husitským obdobím až s česko-uherskými válkami, v intervalu se musí zohlednit i vojenské aktivity kolem poloviny 15. století. Drobná šlechtická válka, která je známa díky půhonným zápisům, byla trvalou hrozbou v průběhu 15 . století.

Změna v chování Valdštejnů od drobné války a vydržování si bojové družiny v první třetině 15. století jako druhu ekonomiky se projevuje skupováním zaniklých vesnic a vytvářením územně kompaktního panství bez menších intruzivních majetkových ostrůvků cizích vlastníků a představuje základ ekonomického vzestupu panství již na konci 15. století a v první tř̌etině 16. století.

Archeologické prameny dokládají násilný zánik hradu Rokštejna, který lze př̀i kombinaci archeologické a zvláště historické rekonstrukce vložit do druhé třetiny roku 1467. Zánik vesnice Stančice lze interpretovat jako katastrofický, provázený silným požárem, s ponecháním veškerého inventáře na původním místě (Mazáčková-Doležalová 2012, 268-280). Zánik vesnice Střenčí byl patrně ovlivněn zemědělským využitím intravilánu vesnice a spíše odpovídá pozvolné destrukci vesnice po jejím opuštění (Mazáčková v tisku). U dalších prozatím zběžně prospektovaných lokalit, jako zaniklá Lhotka, Regenholz, Pfaffendorf, Jeníšov II, lze doložit výskyt mazanice, keramiky a kovových artefaktů. Jen o Pfaffendorfu se lze vyjádřit, že katastrofa, která se výrazně projevila ve Stančicích, postihla i tuto lokalitu. Nejednoznačnou výpověd' písemných pramenů o charakteru zániku a jeho relativní dataci doplní až archeologické vyhodnocení.

V regionu se objevují sídla se zemědělskou ekonomikou, dále sídla s kombinovanou ekonomikou s převládající zemědělskou složkou a čistě hornické osady s přímou vazbou na dolování. Příliv horníků do regionů za těžbou stříbra na severu a zlata na jihu představoval od 13. století silný ekonomický a sociální faktor ovlivňující vývoj osídlení a přeměnu krajiny. Stříbro přineslo ekonomickou prosperitu nově založenému královskému městu Jihlava. Patrně výskyt a těžba zlata dovolila šlechtickým rodům jižně Brtnice k etablování jejich mocenské domény. V blízkosti těžby vznikala hornická sídla. S úpadkem dolování zaniklo i sídlo s úpravnou rud (např. Hrubý-Petr-Hejhal 2012; Hrubý-Malý-Milo 2016). Písemné prameny dovolují rekonstruovat situaci v okolí Předína, Dašovic a Štěměch jako území s možným ekonomickým potenciálem k těžbě, které se objevuje v majetku hraběte Jana z Hardeggu nebo těšínského vévody Přemka.

Zánik lokalit evidovaných v písemných pramenech jako zaniklé se koncentruje do období po polovině 15 . století a dále na konec 15 . století. První zmínky z regionu o zaniklých vsích jsou již z roku 1399. Od této doby až do změny vlastníka panství Brtnice v roce 1623 se udrželo přerozdělování původního zemědělského zázemí těchto zaniklých sídel.

Článek vznikl za podpory Grantového fondu pro akademické pracovníky Filozofické fakulty Masarykovy univerzity, projektu „Kolaps zemědělského zázemí na Jihlavsku a přeměna Brtnického dominia v 15. století".

\section{Prameny}

MZA, fond G 10 Sbírka rukopisů Moravského zemského archivu, inv. č. 638, dříve inv. č. 575 - Urbář panství brtnického $\mathrm{z}$ doby před r. 1538 .

MZA, fond G 169 Collaltové, č. I. 2562 - Urbář panství Brtnice r. 1570.

MZA, fond G 169 Collaltové, č. I. 2561 - Urbář panství Brtnice r. 1585.

MZA, fond F 16 Velkostatek Brtnice, mapy 1033, 1034, 1035, 1038, 1068, 1070, 1072, 1073.

Edice

AČ II: Archiv Český čili staré písemné památky české a moravské II (Palacký, F., ed.). Praha 1842.

AČ III: Archiv Český čili staré písemné památky české a moravské III (Palacký, F., ed.). Praha 1844.

AČ VII: Archiv Český čili staré písemné památky české a moravské VII (Kalousek, J., ed.). Praha 1840.

AČ X: Archiv Český čili staré písemné památky české a moravské X (Kalousek, J., ed.). Praha 1890.

AČ XIV: Archiv Český čili staré písemné památky české a moravské XIV (Kalousek, J., ed.). Praha 1895. 
AČ: IX: Archiv Český čili staré písemné památky české a moravské IX (Kalousek, J., ed.). Praha 1889.

CDB II: Codex diplomaticus et epistolaris regni Bohamie. Tomus II (Fridrich, G., ed.). Pragae 1912.

CDB III/1: Codex diplomaticus et epistlorais regni Boheminae III/1 (Fridrich, G., ed.). Pragae 1942.

CDB V/1: Codex diplomaticus et epistlorais regni Boheminae V/1 (Šebánek, J.-Dušková, S., edd.). Pragae 1976.

CDB V/2: Codex diplomaticus et epistlorais regni Boheminae V/2 (Šebánek, J.-Dušková, S., edd.). Pragae 1981.

CDM III: Codex diplomaticus et epistolaris Moraviae III (Boček, A., ed.). Olmucii 1841.

CDM VI: Codex diplomaticus et epistolaris Moraviae VI (Chytil, J., ed.). Brünn 1854.

CDM VII/1: Codex diplomaticus et epistolaris Moraviae VII/1(Chytil, J., ed.). Brünn 1858.

CDM VII/3: Codex diplomaticus et epistolaris Moraviae VII/3 (Brandl, V., ed.). Brünn 1868.

CDM VIII: Codex diplomaticus et epistolaris Moraviae VIII (Brandl, V., ed.). Brünn 1874.

CDM IX: Codex diplomaticus et epistolaris Moraviae IX (Brandl, V., ed.). Brünn 1875.

CDM X: Codex diplomaticus et epistolaris Moraviae X (Brandl, V., ed.). Brünn 1878.

CIB IV/5: Codex iuris bohemici, IV.-5. Spisy právnické o právu českém v XVI-tém století (Jireček, H., ed.). Vídeň 1883.

Městská správa Jihlava. Inventář. Sv. 1. Listiny (1240) 1269-1900 (1929); (Hoffmann, F.-Křesadlo, K., edd.). Jihlava 1971.

LCS II: Libri citationum et sententiarum. Knihy půhonné a nálezové II (Brand1, V., ed.). Brunae 1873.

LCS III/1: Libri citationum et sententiarum. Knihy půhonné a nálezové III/1 (Brandl, V., ed.). Brunae 1878.

LCS III/2: Libri citationum et sententiarum. Knihy půhonné a nálezové III/2 (Brandl, V., ed.). Brunae 1880.

LCS IV/1: Libri citationum et sententiarum. Knihy půhonné a nálezové IV (Brand1, V., ed.). Brunae 1881.

LCS V: Libri citationum et sententiarum. Knihy půhonné a nálezové V (Brandl, V., ed.). Brunae 1888.

LCS VII: Libri citationum et sententiarum VII (Bretholz, B., ed). Brunae 1911.

Regesten: Regesten der Archive im Merkgrafthume Mähren I (Chlumecký, P., ed.). Brünn 1856.

ZDB I-XIV: Die Landtafel des Markgrathums Mähren. Brünner Cuda (Chlumecký P.-Chytil, J.-Demuth, C.-Wolfskron A. R., edd.). Brünn 1856.

ZDB XV-XXVIII: Moravské zemské desky II. 1480-1566. Kraj brněnský (Kalina, T., ed.). Praha 1950.

\section{Literatura}

BLÁHA, J. a kol., 2001: Bláha, J.-Borovský, T.-Czajkowski, P.-Hodeček, D., Kostel sv. Kunhuty v Kostelci u Jihlavy, PRP 8, č. 1, 104-118.

BLÁHOVÁ, M., 2002: Funkce a pramenná hodnota pamětních zápisů středověkých církevních institucí. Tak zvaná zakládací listina kláštera Třebíčského. In: Ve stopách sv. Benedikta. Sborník příspěvků z konference Středověké kláštery v zemích Koruny české konané ve dnech 24.-25. května 2001 v Třebíči (Jan, L.-Obšusta, P., edd.), 97-111. Brno: Matice moravská ve spolupráci se Západomoravským muzeem v Třebíči.

BLÁHOVÁ, M.-FROLÍK, J.-PROFANTOVÁ, N., 1999: Velké dějiny zemí Koruny české. Svazek 1. Do roku 1197. Praha.

DEMEK, J.-MACKOVČIN, P., 2006: Hory a nížiny. Zeměpisný lexikon. Brno.

FIŠER, R., 2002: K počátkům třebíčského kláštera (Poznámky k tzv. falzu zakládací listiny). In: Ve stopách sv. Benedikta. Sborník př́ispěvků z konference Středověké kláštery v zemích Koruny české konané ve dnech 24.-25. května 2001 v Třebíči (Jan, L.-Obšusta, P., edd.), 85-95. Brno: Matice moravská ve spolupráci se Západomoravským muzeem v Třebíči.

HEJHAL, P., 2012: Počátky středověké kolonizace české části Českomoravské vrchoviny. Disertationes Archaeologicae Brunenses/Pragensesque 14 (Měřínský, Z.-Klápště, J., edd.). Brno.

HOSÁK, L., 1952: Středověká kolonisace horního poříčí Jihlavy, ČSPS LX, 142-153.

HRAZDIL, V. a kol., 2012: Hrazdil, V.-Škrdla, P.-Houzar, S.-Vokáč, M., Historické dolování stř́ibrných rud v Komárovicích u Jihlavy, západní Morava, Acta rerum naturalium: př́írodovědný sborník Vysočiny $12,137-144$.

HRUBÝ, P. a kol., 2006: Hrubý, P.-Jaroš, Z.-Kočár, P.-Malý, K.-Miháyiová, J.-Militký, J.-Zimola, D., Středověká hornická aglomerace na Starých Horách u Jihlavy, PA XCVII, 171-264.

HRUBÝ, P. a kol., 2014: Hrubý, P.-Hejhal, P.-Malý, K.-Kočár, P.-Petr, L., Centrální Českomoravská vrchovina na prahu vrcholného středověku. Archeologie, geochemie a rozbory sedimentárních výplní niv. Brno. 
HRUBÝ, P.-MALÝ, K.-MILO, P., 2016: Archeometalurgie a geofyzika středověkých areálů zaměřených na produkci drahých kovů - Archaeometallurgy and geophysics of the medieval sites specialized on precious metal production, AH 41, 391-413.

HRUBÝ, P.-PETR, L.-HEJHAL, P., 2012: Středověký úpravnický a hornický areál Cvilínek u Černova na Pelhřimovsku - Das mittelalterliche Aufbereitungs- und Bergbauareal Cvilínek bei Černov in der Gegend Pelhřimov, PA CIII, 339-418.

JAN, L., 2000: Vznik zemského soudu a správa Moravy ve středověku. Brno.

LÍBAL, D., 2001: Katalog gotické architektury v České republice do husitských válek. Praha.

LOSERTOVÁ, L. a kol., 2011: Losertová, L.-Buřival, Z.-Losos, Z.-Veleba, B., Pozůstatky po historické těžbě v okolí Humpolce, Acta rerum naturalium: přírodovědný sborník Vysočiny 10, 1-10.

MAZÁČKOVÁ, J., 2011: Obléhací postavení u hradu Rokštejna - Belagerungsstellungen bei der Burg Rokštejn, AH 36, 61-85.

- 2012: Militária z hradu Rokštejna v širším středoevropském kontextu. Rukopis disertační práce, ulož. v ÚAM FF MU, Brno.

- v tisku: Středověká vesnice Českomoravské vrchoviny na příkladu panství Rokštejn a Brtnice. In: Bajer, A.-Bíško, R.-Dejmal, M.-Hejhal, P.-Hrubý, P.-Lisá,L.-Machová, B.-Malý, K.-Mazáčková, J.Plaček, M.-Šabatová, K.-Těsnohlídek, J.-Zimola, D.-Žahourková, A., Historická krajina Českomoravské vrchoviny. Osídlení od pravěku do sklonku středověku. Jihlava.

MAZÁČKOVÁ J.-DOLEŽALOVÁ K., 2012: Stančice, povrchová prospekce a systematické zaměřování zaniklé vsi, Acta Musei Moraviae Scientiae sociales XCVII, č. 2, 259-284.

MĚŘÍNSKÝ, Z., 1976: Průzkum zaniklých středověkých osad na moravské straně Českomoravské vrchoviny, AR XXVIII, 405-417, 479.

- 1977: Středověké hrádky a tvrze na jihozápadní Moravě, AH 2, 37-44.

- 1986: Doba slovanská. In: Pravěké osídlení Třebíčska, 147-171 (Koštuřík, P.-Kovárník, J.-Měřínský, Z.Oliva, M., edd.). Brno - Třebíč.

- 1988: Počátky osídlení Brtnicka a nejstarší dějiny obce. In: Dějiny Brtnice a připojených obcí (Janák, J., ed.), 13-49. Brno.

- 1988a: Brtnice a okolí od poloviny 13. století do válek husitských. In: Dějiny Brtnice a připojených obcí (Janák, J., ed.), 51-99. Brno.

- 1990: Vývoj osídlení Jihlavska do 13. století (Nástin), Vlastivědný sborník Vysočiny, Oddíl věd společenských VII, 129-141.

- 1997: Od připojení Moravy v rámec českého státu do válek husitských. In: Moravskobudějovicko - Jemnicko. Vlastivěda moravská (Nekuda, V., ed.), 151-238. Brno.

- 2002: Církevní instituce na Moravě a historické pozadí vzniku třebíčského kláštera. In: Ve stopách sv. Benedikta: sborník příspěvků z konference Středověké kláštery v zemích Koruny české konané ve dnech 24.-25. května 2001 v Třebíči (Jan, L.-Obšusta, P., edd.), 57-83. Brno: Matice moravská ve spolupráci se Západomoravským muzeem v Třebíči.

- 2007: Hrad Rokštejn. Dějiny, stavební vývoj a výsledky čtvrtstoletí archeologického výzkumu 19812006. Brtnice - Brno.

- 2009: Vývoj osídlení Jihlavska. In: Jihlava. Historie / kultura / lidé. Dějiny moravských měst (Pisková, R., ed.), 33-37. Jihlava.

- 2014: K počátkům Brtnice. Konfrontace písemných a archeologických pramenů, analýza půdorysu obce a jejího stavebního vývoje. In: Středověká Evropa v pohybu. K poctě Jana Klápště (Boháčová, I.Sommer, P.-Bentz, E., edd.), 87-103. Praha.

MĚŘÍNSKÝ, Z.-CHAROUZ, J. Z., 2009: Vznik Staré Jihlavy s kostelem sv. Jana Křtitele a zdejší markraběcí zboží. In: Jihlava. Historie / kultura / lidé. Dějiny moravských měst (Pisková, R., ed.), 38-45. Jihlava.

MĚŘÍNSKÝ, Z.-PLAČEK, M., 1989: Rokštejn, středověký hrad na Jihlavsku (jeho dějiny, stavební vývoj a výsledky archeologického výzkumu 1981-1989). Brno - Brtnice.

MĚŘÍNSKÝ, Z.-ZUMPFE, E., 2001: Der Bergbau und die Besiedlung des südwestlichen Mährens - Hornictví a osídlování jihozápadní Moravy, AH 26, 15-25.

NAVRÁTIL V., 1986: Uspořádání sídla a plužiny - Pramen k dějinám osídlení úzce vymezeného regionu, HG 25, 53-96.

- 1986a: K povrchovému průzkumu zaniklých středověkých osad a jejich plužin na jihozápadní Moravě, HG 25, 201-229.

NEKUDA, V., 1961: Zaniklé vesnice na Moravě. Brno.

RICHTER, V., 1952: Románská architektura na Moravě, ČSPS LX, 231-234.

- 1961: Přechodní stavby v údolí Jihlávky, Vlastivědný sborník Vysočiny, Oddíl věd společenských IV, 23-37. 
ROBOTKA, M.-STRÁŽNICKÝ, J., 1967: Komplexní průzkum půd ČSSR. Průvodní zpráva k hospodářskému obvodu JZD „Rovnost“ se sídlem v Brtnici okres Jihlava, Brno. Dostupné z: http://wakpp.vumop. $\mathrm{cz} /$.

ROUS, P., 2004: Stř́ibrnorudné hornictví na Havlíčkobrodsku od 13. do 17. století, Archeologia technica $15,49-58$.

SAMEK, B., 1994: Umělecké památky Moravy a Slezska. 1. svazek. A/I. Praha.

- 1999: Umělecké památky Moravy a Slezska. 2. svazek. J/N. Praha.

SEDLÁČEK, A., 2003: Atlasy erbů a pečetí české a moravské stř̌edověké šlechty. Svazek 5. Atlas pečetí.

VOHRYZEK, S., 2012: Střížovci v 2. polovině 14. století, AVV 3, 67-74.

- 2013: K počátkům působení pánů z Valdštejna na jihozápadní Moravě, AVV 4, 84-90.

- 2015: Dějiny panství Stonařov do roku 1530, Vlastivědný sborník Vysočiny, Oddíl věd společenských XIX, 36-67.

VOKÁC̆, M.-HOUZAR, S.-ŠKRDLA, P., 2007: Dolování zlata v širším okolí Hor u Předína na západní Moravě: dějiny výzkumů, historie dolování, topografie a archeologie lokalit a přehled geologických poměrů. In: Stř́íbrná Jihlava. Studie k dějinám hornictví a důlních prací, 26-55. Jihlava.

VOKÁČ, M.-ZIMOLA, D., 2011: Archeologické výzkumy několika venkovských kostelů na Jihlavsku Ländliche Sakralarchitektur in der Region Jihlava, AH 36, 431-453.

ZAORALOVÁ, M., 1988: Od husitství k Bílé hoře (Brtnice v majetku Brtnických Valdštejnů). In: Dějiny Brtnice a připojených obcí (Janák, J., ed.), 101-132. Brno.

\section{Zusammenfassung}

\section{Skizzierung des Wüstungsprozesses von Ansiedlungen im Mittelalter im Einzugsgebiet der Grundherrschaft Brtnice (Pirnitz) zum Jahr 1538}

Um die Besiedelung der Grundherrschaft Brtnice (Pirnitz), dem die Grundherrschaft Rokštejn (Ruckstein) vorausging, in den im Urbarium zum Jahr 1538 angegebenen Grenzen (Mährisches Landesarchiv, Bestand G 10, Inv.-Nr. 638) zu rekonstruieren, ist die vorhergehende historische Entwicklung und die bis dato ermittelte Wirtschaftstruktur der Siedlungen mit Dorfcharakter wichtig. Die Ausdehnung des Gebietes der Grundherrschaft Rokštejn stellt mehrere grundlegende Entwicklungsstadien dar (Abb. 6). Die Existenz der ursprünglichen Grundherrschaft mit seinem Zentrum in Stř́žzv (Strieschow), von wo aus es zur Gründung der Burg Rokštejn gekommen war, wird anhand mehrerer Fakten rekonstruiert. Die im Dorf stehende Kirche St. Johannes der Täufer mit ihrem polygonalem Abschluss und dem Kirchenschiffaufbau bekennt sich bereits zur Mitte des 13. Jahrhunderts, ebenso auch die während Oberflächensammlungen entdeckte rädchenverzierte Keramik aus der ersten Hälfte des 13. Jahrhunderts von der Stř́žover Parzelle Nummer 236/16. Die Gesamtkonzeption des Chorraums der Kirche gehört dem Charakter der Gewölbe nach erst in das dritte Viertel des 14. Jahrhunderts. D. Líbal rechnet bereits in der ersten Hälfte des 14. Jahrhunderts mit der Fertigstellung der Stř́ížover Kirche, obgleich die Fenster den Charakter des 13. Jahrhunderts haben. Zahlungen für den Bau in Stř́žov sowie mit dem Zehnt in Komárovice (Komarowitz) erfolgte Transaktionen erlauben es, den Bau oder eher Umbau des Chorraums in die Zeit um das Jahr 1367 zu legen (Líbal 2001, 471; Richter 1952, 232; Vohryzek 2012, 70). Mit dem Bau einer Steinburg sind die Ruthensteins/Stř́žzov in der untersuchten Region als einziges Adelsgeschlecht in repräsentativer Form einen Rang höher gerückt als der benachbarte Adel. Markgraf Heinrich war es, der den markgräflichen Erwerb der Burg Rokštejn mit ihrem Hinterland in der zweiten Hälfte des 14. Jahrhunderts in den Quellen einführte und auf den im Jahr 1366 erfolgten Kauf der Burg verwies (CDM IV, 323-325 Nr. 420; Vohryzek 2013, 68).

Die Oberflächenprospektion und die Vermessung der anthropogenen Relikte, die sich mit Siedlungswüstungen oder direkt mit speziellen Siedlungswüstungen wie es mittelalterliche Dörfer mit belegbarem ursprünglichen Namen sind, identifizieren lassen, zählen zu den grundlegenden und hauptsächlichen Quellen, um Erkenntnisse über die mittelalterliche Besiedelung in diesem Gebiet zu gewinnen. So wird ein einzigartiger Komplex an Fakten an einem Ort gebildet, 
der nach dem Untergang von Ansiedlungen durch verschiedene natürliche und anthropogene Prozesse beeinflusst wurde, wie etwa durch Wiederaufforstung bei einem Eigentümerwechsel der Herrschaft, die den Aussagewert des Komplexes konservieren oder deutlich mindern können. In dem untersuchten Gebiet gibt es belegbare deutliche anthropogene Relikte, die Reste ursprünglicher Dorfsiedlungen mit einer landwirtschaftlich geprägten Wirtschaft darstellen. Die Fundstellen um die es sich handelt liegen heute in einem aufgeforsteten Raum wie etwa in den Wäldern Sokolíčko, Lhotka (Wüstung Lhotka), Aleje (Wüstungen Stančice und Střenčí) und Zákopy (Wüstung Jeníšov). Die Aufforstung ist auf historischen Karten belegt, und zwar auf der Müller'schen Karte von Mähren, auf den Karten der I. und II. militärischen Kartierung sowie auf Indikationsskizzen. Das aufgeforstete Gebiet wird auch von den Archivkarten der Waldreviere der jeweiligen Herrschaften Jihlava (Iglau) oder Brtnice dokumentiert und die Entwicklung wird auch durch die Ortsnamen verdeutlicht (Mährisches Landesarchiv, Bestand F 16, Karte 1033). Die Wälder Sokolíčko, Lhotka und V Zákopech südöstlich von Opatov (Opatau) stellen Wirtschaftswälder ohne absichtliche Vorparzellierung dar wie etwa bei dem Wald Aleje, der in der Zeit zwischen 1815-1817 im Rahmen der Errichtung eines Jagdschlosses durch Fürst Eduard Collalto bedeutende Änderungen erlebte (Samek 1994, 262). Bei den nach der Schlacht am Weißen Berg erfolgten Konfiszierungen ging die Grundherrschaft Brtnice im Jahr 1623 in den Besitz der Familie Collalto über. Nach dem Dreißigjährigen Krieg kam es offenbar zu einer Aufforstung der genannten Reviere Sokolíčko, Lhotka, Aleje und V Zákopech (Abb. 2).

Bei der Ermittlung des Wirtschaftspotenzials der Grundherrschaft sind wir vornehmlich auf schriftliche Quellen angewiesen, in denen vor allem der landwirtschaftliche Charakter der Besiedelung aufgeführt wird. Die Landwirtschaft machte sich an den Orten, die in den Dorfwüstungen ursprünglich bestellt worden waren, bei der Umverteilung des Bodens an die Bewirtschafter der umliegenden Ansiedlungen auch weiterhin bemerkbar. Trotzdem tauchen in der Umgebung oder im direkten Umkreis des landwirtschaftlichen Hinterlandes der Siedlungswüstungen Belege für den Abbau von Edelmetallen auf (Abraumhalden, Pingen). Die historische Konstruktion der Besiedelung und die Wechsel der Eigentümer erlauben es, einen Einblick in den möglichen Komplex der ökonomischen Strukturen und deren Entwicklung bei den Siedlungswüstungen zu bekommen. Die Aufnahme einer Dorfwüstung mit Flurland in den Kataster einer anderen Ansiedlung und die Absorption ihres wirtschaftlichen Hinterlandes (z.B. Jestřebí bei Brtnice) ist erst ab der Entstehung von Indikationsskizzen in den dreißiger Jahren des 19. Jahrhunderts im Anschluss daran dokumentiert, dass sich die Entwicklung der wirtschaftlichen Struktur der Herrschaft veränderte und Bereiche, die diesen Typ Agrarboden hatten, aufgeforstet wurden.

Über die Art und Weisen und die Ursachen des Untergangs einer dörflichen Besiedelung geben die schriftlichen Quellen keine Auskunft. Lediglich bei Orten mit zentraler Funktion wird die Art und Weise des Untergangs aufgeführt, beispielsweise durch einen militärischen Überfall wie im Falle von Štěměchy (Stiemich) um das Jahr 1409 oder 1468 (LCS II, 168 Nr. 674). In den historischen Analysen oder Interpretationen der archäologischen Situationen sind Untergänge mit der unruhigen Hussitenzeit bis einschließlich den böhmisch-ungarischen Kriegen verbunden. In diesem Zeitintervall müssen auch die militärischen Aktivitäten um Mitte des 15. Jahrhunderts berücksichtigt werden. Der aufgrund der Zitationsbücher bekannte Kleinkrieg des Adels stellte während des 15. Jahrhunderts eine ständige Bedrohung dar. Trotzdem können durch die historische Konstruktion mehrere Untergangshorizonte der Ansiedlungen festgelegt werden. Den ersten Horizont umfasst eine Aufstellung der den Klöstern in Třebíč (Trebitsch) und Louka (Klosterbruck) bei Znojmo (Znaim) im 12. Jahrhundert gestifteten Güter. In den dreißiger Jahren des 13. Jahrhunderts folgen dann Aufstellungen der Besitztümer verschiedener Eigentümer oder der Zehntdörfer der Kirchen in Přibyslavice (Pschibislawitz), Jihlava und Brtnice (zuletzt zusammenfassend Mazáčková 2012, 130-131, Tab. 13). Im Laufe des 12. und 13. Jahrhunderts entstand dort ein Siedlungsnetz, wovon ein Teil zum landwirtschaftlichen Charakter der jüngeren Besiedelung im 14. Jahrhundert keinen Bezug hat. Ab dem 14. Jahrhundert (1399, Lhotka) tauchen auf den Landtafeln Einträge von Siedlungswüstungen und deren Übertragung sowie 
Kodifizierung als auf verschiedene Eigentümer übertragene Eigentumsgebietskomplexe auf. Dabei handelt es sich um gebietsmäßig ordentlich abgegrenztes wirtschaftliches Hinterland von wenn auch untergegangenen - Dörfern, das nicht auf die umliegenden Ansiedlungen umverteilt und nicht zerstückelt wurde (siehe Dorfwüstung Ostejkovice), sondern durch seine Vermessung weitere Besitztransaktionen und eine anschließende landwirtschaftliche Nutzung ermöglicht wurde. In Landtafeln und Zitationsbüchern wird bei Ansiedlungen die Bezeichnung wüst deserta - aufgeführt. Diese Praxis wurde auch in den im 16. Jahrhundert angelegten Urbarien der Grundherrschaft Brtnice übernommen, in denen nicht nur die Namen der Dörfer, sondern auch ihre ursprünglichen Abmessungen beibehalten wurden. Bei im Laufe des 13. Jahrhunderts untergegangenen Dörfern war es zu keiner solchen landschaftlichen und rechtlichen Verankerung gekommen. Deshalb kann man festhalten, dass es im Verlauf des 14. Jahrhunderts zu einer Stabilisierung der Abmessungen des wirtschaftlichen Hinterlandes der Dörfer gekommen ist. Die Eigentümer von wüsten Ansiedlungen disponieren auch weiterhin über das Hinterland und lassen es gegen feste Zahlungen in verschiedene Grundstücke bestellten oder unbestellten Bodens einschließlich Wald aufteilen. Die Pachthöhe für die Grundstücke schwankte jeweils. Die Verpachtung an die Bauern der umliegenden Ansiedlungen in der Herrschaft wurde auch auf Personen außerhalb der Grundherrschaft Brtnice ausgeweitet, diese stammten beispielsweise aus Stonařov (Stannern) oder Dlouhá Brtnice (Langpirnitz). Im Falle der Dorfwüstung Střenčí handelt es sich um Ansässige aus Jestřebí (Haslitz), Brtnice (Pirnitz), Kněžice (Knieschitz), Víska (Dörfel), Brtnička (Klainpirnitz), Malá Brtnice (Klein Pirnitz), Dlouhá Brtnice (Langpirnitz) und Stonařov (Stannern); (Mährisches Landesarchiv, Bestand G 10, Inv.-Nr. 638, fol. 109-113).

Die Entwicklung einiger bereits im 13. Jahrhundert entstandener, benachbarter Herrschaften in der Umgebung der Herrschaft Rokštejn - und zwar der Herrschaften der Familien Marquart von Hrádek, der Herren von Herlitz (Heraltice), der Familie Ranožír und der Familie Hrutow von Knieschitz - zeigt auf, dass die Herrschaft im Verlauf des 15. bis zum Beginn des 16. Jahrhunderts langsam und systematisch in den Besitz der Familie Waldstein gelangte. Die Wirtschaft der Waldstein war bestrebt, ein kompaktes Gebiet mit Verwaltungszentrum zu schaffen. Sie konzentrierte sich auf Landwirdschaft und die systematische Umverteilung der Gebiete von Dorfwüstungen für eine landwirtschaftliche Tätigkeit, ebenso wie auf die Anlage von Teichen zur Fischzucht. Der in den jüngeren schriftlichen Quellen als wüst erfasste Untergang von Standorten konzentriert sich in die Zeit nach Mitte des 15. Jahrhunderts und ferner zum Ende des 15. Jahrhunderts. Die Umverteilung des ursprünglichen landwirtschaftlichen Hinterlandes dieser Siedlungswüstungen hielt ab dieser Zeit bis zum Jahr 1623 an, als die Herrschaft Pirnitz ihren Besitzer wechselte.

Mgr. Jana Mazáčková, Ústav archeologie a muzeologie Filozofické fakulty Masarykovy univerzity, Joštova 13, 66243 Brno, Česká republika,jkrejsov@phil.muni.cz 
